\title{
The role of loss of self-control in defences to homicide: a critical analysis of Anglo-Australian developments
}

\author{
Heather Douglas \\ University of Melbourne \\ Alan Reed \\ Northumbria University \\ Correspondence email: douglash@unimelb.edu.au
}

\begin{abstract}
The provocation defence has been the subject of legislative reform in England and Australia over the past 10 years. In England, it was abolished by section 56 of the Coroners and Justice Act 2009 and replaced with a partial defence of loss of control. In Australia, the provocation defence has been abolished in some states and significantly reformed in others. One of the key challenges for law reform has been how to ensure homicide defences are not overly restrictive for abused women who kill their abuser, while at the same time ensuring that homicide defences are not overly expansive for domestic abusers who ultimately kill their partner. With these challenges in mind, we critically examine the operation of the loss of control defence in England. There has been significant reform to the provocation defence across Australia, and, in this article, we also focus on the most recent reforms in Queensland and New South Wales. We conclude with some suggestions for further reform.
\end{abstract}

Keywords: Anglo-Australian provocation defence; homicide; loss of control; Coroners and Justice Act 2009; domestic abuse; coercive control; provocation triggers; serious violence; sexual infidelity; separation; jury directions.

\section{INTRODUCTION}

Drovocation was abolished as a partial defence to murder in English law by section 56 of the Coroners and Justice Act 2009 (CJA), effective from 4 October 2010. Reforms promulgated a new loss of control iteration, predicated on novel qualifying triggers, derived from fear of serious violence and imperfect justification, and with bespoke 'apparent' exclusions for sexual infidelity and revenge killings. Significantly, the legislative response charted a paradigm shift from jury evaluation of the normative characteristics of the reasonable defendant at common law towards contemplation of all of 
the circumstances leading up to the fatal action. It was uncertain under prior provocation standardisations which individuated characteristics of the defendant were relationally relevant for juror consideration as a modulation of the amorphous reasonable person contextualisation. ${ }^{1}$

This article contextualises Anglo-Australian theoretical and substantive developments that have occurred in the last decade since the introduction of the loss of control framework for voluntary manslaughter in England. Australian reforms in the two states of New South Wales (NSW) and Queensland (Qld) have aimed to ensure that in exceptional cases, abused women who kill are able to rely on the defence of provocation. At the same time, they have aimed to ensure that male proprietorial anger does not excuse a fatal response. Our comparative review focuses upon whether new models of defences involving loss of control have shifted the partial defence from one viewed through a lens of male proprietorial anger to a defence that reflects culpability standardisations for victims of domestic abuse who kill abusive partners. Lessons are drawn from Australian initiatives that have occurred over the intervening 10-year period, including Social Framework Evidence and enhanced juror directions.

We include a critique of the 'fear of serious violence' qualifying trigger as a different configuration of loss of control with elaboration on the fluidity and polysemicity of the signs and manifestations of fear. The threshold hurdles for the defence to overcome to successfully plead a provocation defence are analysed. Further, this article reviews the unanticipated consequences that have occurred via the apparent exclusion of consideration of sexual infidelity in provoked killings. It addresses the standardisation of the normative 'reasonable' killer in such contextualisations. The article concludes with optimal AngloAustralian reform proposals to reflect a new comparative pathway for abusive partner and sexual infidelity killings and consideration of rational 'half-way house' defence alternatives.

\section{THE CORONERS AND JUSTICE ACT 2009 REFORMS: GROSS PROVOCATION AND IMPERFECT JUSTIFICATION}

The defence of provocation in crimes of homicide has always represented an exceptional mitigatory factor in English law. In violent crimes that resulted in injury short of death, the fact that the accused committed the violent act under provocation did not affect the nature

1 Sarah Sorial, 'Anger, provocation and loss of self-control: what does 'losing it' really mean?” (2019) 13 Criminal Law and Philosophy 247. 
of the offence. ${ }^{2}$ The fact that the provocation caused the accused to lose her self-control was merely a matter to be taken into consideration in determining the appropriate penalty to impose. In homicide, however, provocation effected a change in the offence, reducing it from murder, for which the penalty became imprisonment for life, to manslaughter, where the penalty lay at the discretion of the judge. ${ }^{3}$ As Simester et al have commented, 4 the derivations of this form of extenuation may be traced back to verdicts of medieval judges, whereby certain spontaneous angry killings were dispositively contextualised as killings se defendo, indulgently abrogating a verdict of murder, and with attendant implications. 5

The CJA legislative reforms replaced provocation with a bespoke and constrained defence of loss of control. 6 It is straitened by subjectivisation to specific qualifying triggers, but the partial nature of the defence was retained, aligned with a corresponding burden of proof on the prosecution. ${ }^{7}$ A triumvirate of new threshold elements was adopted, disaggregating the former provocation nomenclature. The ambit of the defence, in part determined by governmental policy rationale, was significantly narrowed, vituperatively criticised in parliamentary debates prior to enactment as 'all over the place', 'beyond redemption' and a 'dog's breakfast'. ${ }^{8}$ A marked shift towards objectification occurred throughout the reforms, and the trial judge can now remove the defence from consideration on the predicate that no properly directed jury could reasonably conclude its applicability. ${ }^{9}$

$2 \quad$ DPP $v$ Camplin [1978] AC 705, 713 per Lord Diplock. Notably, there is an exception to this in the jurisdiction of Qld, Australia, where provocation is a complete defence to assault, see ss 268 and 269 QCC.

3 Timothy Macklem, 'Provocation and the ordinary person' (1987) 11 Dalhousie Law Journal 126; Alan Reed, 'Duress and provocation as excuses to murder: salutary lessons from recent Anglo-American jurisprudence' (1996) 6 Florida State University, Journal of Transnational Law and Policy 51.

4 A P Simester, J R Spencer, F Stark, G R Sullivan and G J Virgo, Simester and Sullivan's Criminal Law: Theory and Doctrine 6th edn (Hart 2019) 408-422.

$5 \quad$ Ibid 408.

6 Carol Withey, 'Loss of control: loss of opportunity?' [2011] Criminal Law Review 263.

7 Alan Norrie, 'The Coroners and Justice Act 2009 - partial defences to murder (1) loss of control' [2010] Criminal Law Review 275.

8 Jo Miles, 'A dog's breakfast of homicide reform' (2009) Archbold News 6; Amanda Clough, 'Loss of self-control as a defence: the key to replacing provocation' (2010) 74 Journal of Criminal Law 127; Stanley Yeo, 'English reform of provocation and diminished responsibility: whither Singapore?’ (2010) Singapore Journal of Legal Studies 177.

9 CJA, s 54(6); Susan S M Edwards, 'Anger and fear as justifiable preludes for loss of self-control' (2010) 74 Journal of Criminal Law 223. 
The reformed defence posits three hurdles for the defence to overcome or, more transformatively, three opportunities for the Crown to disprove it. The first requirement is subjective, retaining the controversial threshold that the killing resulted from the accused's (partial) loss of control.10 An individual loss of control, contrary to old provocation law derived from the much-criticised Duffy ${ }^{11}$ standardisation, no longer needs to be 'sudden' and 'temporary'. This criterion had clearly prejudged certain societal groupings, notably identified in a number of high-profile cases where battered women, as primary victims, had responsively killed their abuser, but after a temporally individuated delay between the final provoking event and fatal action.12 A concern was that this particular group of female primary victims commonly reacted in a phenomenologically different manner (slow-burn) than the male response to provoking stimuli, which translated as immediate aggressive anger. ${ }^{13}$

The retention of the loss of control imperative, considered further below, means that, as Fortson has contended, defence counsel still unfortunately transmogrify back to the utilisation of descriptors often heard in cases of common law provocation such as 'snapped', 'went berserk', 'lost the plot', and 'the straw that broke the camel's back', which are not necessarily helpful when deciding whether the partial defence has been made out. ${ }^{14}$ The defence will not operate where the defendant has acted in a considered desire for revenge, which is emotionally inconsistent with a loss of self-control contextualisation. ${ }^{15}$

The second threshold hurdle of the classificatory schema interposed new qualifying triggers. Constitutively, it presents the only type of emotional excuse that is validated to potentially offer a partial

10 CJA, s 54(1)(a); Nicola Wake, 'Political rhetoric or principled reform of loss of control? Anglo-Australian perspectives on the exclusionary conduct model' (2013) 77 Journal of Criminal Law 512.

11 [1949] 1 All ER 932; Susan S M Edwards, 'Justice Devlin's Legacy: Duffy - a battered woman caught in time’ [2009] Criminal Law Review 851.

12 Aileen McColgan, 'In defence of battered women who kill' (1991) 18 Journal of Law and Society 219.

13 Joshua Dressler, 'Battered women who kill their sleeping tormentors: reflections on maintaining respect for human life while killing moral monsters' in Stephen Shute and Andrew Simester (eds), Criminal Law Theory (Oxford University Press 2002) 259: Edwards (n 9 above) 225-229.

14 Rudi Fortson, 'Homicide reforms under the CAJA 2009' (Criminal Bar Association of England and Wales Seminar, October 2010). Further bespoke training may be required to properly conceptualise the actual meaning behind loss of self-control.

15 CJA, s 54(4); and see Andrew Ashworth, 'Homicide, Coroners and Justice Act 2009 section 54 - loss of control - qualifying trigger' [2012] Criminal Law Review 539,542 , who states that: '[A] desire for revenge that may fairly be described as fleeting or instinctive stands at one end of the spectrum, and a "considered desire for revenge" is well on the way to the other end of that spectrum.' 
exemption. Imperfectly justified anger is mandated, and the qualifying trigger is satisfied by a thing said or things done or said (or both) which constituted circumstances of an extremely grave character and caused the defendant to have a justifiable sense of being seriously wronged.16 Fear is the only other emotion that is supererogatory, with the trigger requiring the defendant to fear violence from the victim against the defendant, or another identified person. ${ }^{17}$ The partial defence is unavailable to the inciter of violence, 18 and controversially anything done or said related to sexual infidelity is denied jury recognition. ${ }^{19}$ This apparent exclusion, however, reviewed in Clinton, 20 is more attenuated than English legislators presupposed.21 Normatively, within the third element of the reformulated template, the jury are to assess whether a person of the defendant's sex and age, with a normal degree of tolerance and self-restraint, and in the circumstances of the defendant, might have reacted in the same way, or in a similar manner. ${ }^{22}$ The defendant's circumstances prior to the killing are subject to factfinder evaluation, apart from those circumstances which only bear on her general capacity for tolerance and self-restraint. ${ }^{23}$

The legislative reforms represented a significant momentum shift, beyond the apparent exclusion of infidelity more generally, trammelling a bifurcation away from a broad hybrid and eclectic excuse-based defence towards a more constrained imperfect justification predicate. 24 This partial justification of paradigmatic inculcation reflected normative beliefs in fear and anger in strictu sensu, as partially appropriate responses to causally related behaviour of the provoker:25 '[T]he new

16 CJA, s 55 (4).

17 Ibid s 55 (3).

18 Ibid s 55 (6)(9).

19 Ibid s $55(6)(\mathrm{c})$.

20 [2012] EWCA Crim 2.

21 See Dennis J Baker and Lucy X Zhao, 'Contributory qualifying and non-qualifying triggers in the loss of control defence: a wrong turn on sexual infidelity' (2012) 76 Journal of Criminal Law 254; and Alan Reed and Nicola Wake, 'Sexual infidelity killings: contemporary standardisations and comparative stereotypes' in Alan Reed and Michael Bohlander (eds), Loss of Control and Diminished Responsibility: Domestic Comparative and International Perspectives (Ashgate 2011) 115.

22 CJA, s 54 (1)(c).

23 Ibid s 54(3). See also Janet Loveless, ' $R v G A C$ : battered woman syndromization' [2014] Criminal Law Review 635, for a criticism of the objectification of learned helplessness vis-à-vis loss of self-control.

24 Norrie (n 7 above) 276-277.

25 Susan S M Edwards, 'When his anger is worth more than her fear' in Reed and Bohlander (n 21 above) 79, who asserts: '[H]abitual gendered thinking will continue to impress on the construction of what is a qualifying trigger ... [W]omen will still be required to lose self-control in the conventional way, and her fear will not be understood.' 
defence moves from a defence based on angry loss of control to one based on righteous indignation or moral outrage.'26 This mirrors recent developments in Australia, notably NSW, where in terms of gross provocation a requirement prevails that the provocative act must be a serious indictable offence, and interpretational difficulties in this contextualisation are comparatively reviewed herein. In England, reforms were anticipated to cathartically and efficaciously address the plight of the domestic abusee, primordially female, who fatally killed her partner. ${ }^{27}$ The sections that follow, reveal that further changes in Anglo-Australian provocation laws are needed to meet designated aspirations of equal and just disposal, a clarion call that Edwards ${ }^{28}$ and other commentators ${ }^{29}$ have cogently advanced:

[I]n the Coroners and Justice Act 2009 ... despite some gains for abused women, the alchemy persists, and while certainly holding the abused woman within its contemplation for a moment she who kills out of fear with all its despair, hopelessness, sorrow, helplessness, anguish and trauma, is still required to lose self-control ... [B]ut the legal template of loss of self-control ... remains soldered to a male angered reaction with its outward demonstration embedded in a legacy of serious wrongs and justifiable hubris. ${ }^{30}$

26 Jonathan Herring, 'The serious wrong of domestic abuse and the loss of control defence', in Reed and Bohlander (n 21 above) 66.

27 Vanessa Bettinson, 'Criminalising coercive control in domestic violence cases: should Scotland follow the path of England and Wales?' [2016] 165; Julia Tolmie, 'Coercive control: to criminalize or not to criminalize' (2018) 18 Criminology and Criminal Justice 50.

28 Susan S M Edwards, 'Loss of self-control: the cultural lag of sexual infidelity and the transformative promise of the fear defence' in Alan Reed and Michael Bohlander (eds), Homicide in Criminal Law: A Research Companion (Routledge 2019) 82-101.

29 E Sheehy, J Stubbs and J Tolmie, 'Securing fair outcomes for battered women charged with homicide: analysing defence lawyering in $R v$ Falls' (2014) 38 Melbourne University Law Review 666; Nicola Wake, 'His home is his castle, and mine is a cage: a new partial defence for primary victims who kill' (2015) 66 Northern Ireland Legal Quarterly 151; S Walklate, K Fitz-Gibbon and $\mathrm{J}$ McCulloch, 'Is more law the answer? Seeking justice for victims of intimate partner violence through the reform of legal categories' (2018) 18 Criminology and Criminal Justice 115.

30 Susan S M Edwards, 'Recognising the role of the emotion of fear in offences and defences' (2019) 83 Journal of Criminal Law 450, 468. See also Susan S M Edwards, 'The strangulation of female partners' [2015] Criminal Law Review 12; Nicola Wake, 'Battered women, startled householders and psychological selfdefence: Anglo-Australian perspectives' (2013) 77 Journal of Criminal Law 433. 


\section{THE SALLY CHALLEN CASE: CONTROLLING/COERCIVE BEHAVIOUR AND THE LIMITS OF LEGISLATIVE REFORMS}

It is not immediately apparent, in any real sense, that an abused woman in an intimate relationship, subjected to coercive and controlling behaviour, is now in a better position to successfully claim a loss of self-control as a partial defence to homicide than 10 years previously via provocation at common law. It has not proved the panacea many commentators hoped it would prove. ${ }^{31}$ The triumvirate of threshold hurdles to surmount, within sections 54-56 of the CJA, as presented above, may be deconstructed in light of the Sally Challen case ${ }^{32}-$ juxtapositionally interpreted under the old common law, but the subject of an appellate review in 2019:33 a review which provided a vignette of extant challenges that still prevail to successfully run any domestic abuse intimate partner killing defence, and chart future reform pathways that we argue should be actioned immediately.

In August 2010, Sally Challen, then aged 56, killed her 61-year-old husband Richard Challen at their family home in Surrey with at least 20 blows of a hammer. The marriage had endured 31 years, during which time he had been unfaithful on several occasions causing considerable distress, had visited brothels, and demeaned her in front of family and friends. Sally Challen made allegations of anal rape and other sexual assaults, and egregious and continual demands within the matrimonial home, creating an atmosphere of total subservience and reinforced by threats. ${ }^{34}$ The couple separated, but in June 2010 a reconciliation transpired, a decree nisi was rescinded, a new post-marital property resettlement was constructed, wholly disadvantageous to Sally Challen, and the couple agreed to sell the family home, and go to Australia for six months. On the day of the fatal attack, the defendant, who remained suspicious about her husband's relationships with other women, met with him to clear out the house and garage in advance of their overseas trip. ${ }^{35}$ In the course of this meeting, the defendant noticed

31 Susan S M Edwards, 'Coercion and compulsion - re-imagining crimes and defences' [2016] Criminal Law Review 876; and Nicola Wake, 'Manslaughter by loss of control: sentencing primary victims who kill' [2019] Criminal Law Review 291.

32 [2019] EWCA Crim 916.

33 Tony Storey, 'Coercive control: an offence but not a defence: $R v$ Challen' (2019) 83 Journal of Criminal Law 513.

34 Note, at the time of Challen's trial, the defence psychiatrist diagnosed her with depression, but not battered women syndrome, presumably because there were no immediate indications of physical violence.

35 Vanessa Bettinson, 'Aligning partial defences to murder with the offence of coercive or controlling behaviour’ (2019) 83 Journal of Criminal Law 71. 
that the phone had been moved, and dialled the last-called number, and realised that her husband had rung another woman. She then proceeded to enact the violent attack during lunch, utilising a hammer that she had brought to the property. Sally Challen was convicted of murdering her husband in 2011, after unsuccessfully pleading diminished responsibility. At the initial trial, provocation was not pleaded, but left to the jury for their consideration. She was sentenced to life imprisonment with a minimum specified period of 22 years. 36

The appeal against conviction, heard eight years subsequently, was on the predicate of fresh psychiatric evidence unavailable at the time of the initial trial. It was suggested that Sally Challen had a borderline personality disorder and a severe mood disorder, specifically bipolar affective disorder, at the time of the killing, and consequentially suffered an 'abnormality of mind', within the contextualisation of diminished responsibility. ${ }^{37}$ It was further contended that evidence of her husband's coercive and controlling behaviour supported the defence of provocation, in that it would have affected the gravity of conduct stipulated as the threshold. 38

In the interim period between conviction and fresh appeal, the nature of coercive/controlling behaviour, and community understanding of the experiences of psychological torment by another ('controlling or coercive behaviour'), had been criminalised as an offence in England by section 76 of the Serious Crime Act 2015.39 Whilst a particularised offence was introduced, no specific defence applied to those who experienced controlling or coercive behaviour. The offence engages causing a person to fear that violence would be used against them on at least two occasions, or where it adversely affects their day-to-day life. 40 New developments in 2020 in England and Wales also led to steps taken to criminalise domestic abuse as an offence, but again not

36 Note an appeal against sentence was allowed and the minimum term was reduced to 18 years: see $R v$ Challen [2011] EWCA Crim 2019.

37 Note that leave to appeal was finally granted in March 2018: $R v$ Challen [2018] EWCA Crim 471.

38 Storey (n 33 above) 513 who states, in the context of fresh evidence of controlling behaviour during their marriage: '[T]his latter argument was supported by, inter alia, the couple's adult sons, David and James Challen, and C's cousin, who said that during their marriage R "pulled the strings" and C "danced".'

39 Edwards (n 31 above) 877.

40 C Wiener, 'What is "invisible in plain sight": policing coercive control' (2017) 56 Howard Journal 500; A Robinson, M C Pinchevsky and J Guthrie, 'Under the radar: policing non-violent domestic abuse in the US and UK' (2016) 40 International Journal of Comparative and Applied Criminal Justice 195; Bettinson (n 27 above) 167. 
a bespoke defence. ${ }^{41} \mathrm{~A}$ wider appreciation of the criminal behaviour engaged in as coercive/controlling behaviour has been presented by a number of commentators, viewed through a lens of 'patriarchal' or 'intimate' terrorism: 42

[A] time period during which the woman may never know when the next incident will occur, and may continue to live with on-going psychological abuse - is to fail to recognise what some battered women experience as a continuing state of siege. 43

Coercive/controlling behaviour engages, as Herring contends, a serious breach of trust within the sphere of an intimate relationship. ${ }^{44}$ Stark, acting as a defence witness, explained to the court in Challen that, in coercive control, abusers deploy a broad range of non-consensual, nonreciprocal tactics over an extended period to subjugate or dominate a partner, rather than merely to hurt them physically. ${ }^{45}$ Compliance, as Stark contends, is achieved by '[M]aking victims afraid, and denying basic rights, resources and liberties, without which an individual is not able to effectively refuse, resist, or escape demands that militate against their interests.' 46 Douglas articulated that broader understanding is required beyond legislative reform to change abusee's experience of

41 The new legislation will create a statutory definition of domestic abuse, emphasising that domestic abuse is not just physical violence, but can also be emotional, coercive or controlling, and economic abuse. It also provides for a new domestic abuse protection order, which will prevent perpetrators from contacting their victims, as well as force them to take positive steps to change their behaviour, for example, by seeking mental health support.

42 Michael Johnson, 'Apples and oranges in child custody disputes: intimate terrorism vs situational couple violence' (2005) 2 Journal of Child Custody 43.

43 Mary Ann Dutton, 'Understanding women's response to domestic violence' (2003) 21 Hofstra Law Review 1191, 1204

44 Herring (n 26 above) 73. See also A Carline and P Easteal, Shades of Grey Domestic and Sexual Violence Against Women (Routledge 2014) 134-135, contending that dissonant public responses apply to self-defence in the contextualisation of domestic abuse killers, contending that the criminal justice system should abrogate intrinsically unfair gendered bifurcations.

45 [2019] EWCA Crim 916. See also Evan Stark, Coercive Control: How Men Entrap Women in Personal Life (Oxford University Press 2007) 363: '[I]n the romantic vernacular, love and intimacy compensate women for their devaluation in the wider world. Personal life does something more. It provides the state where women practice their basic rights, garner the support needed to resist devaluation, experiment with sexual identities, and imagine themselves through various life projects. Coercive control subverts this process, bringing discrimination home by reducing the discretion in everyday routines to near zero, freezing feeling and identity in time and space, the process victims experience as entrapment.'

46 [2019] EWCA Crim 916; and see also Evan Stark, 'Re-presenting battered women: coercive control and the defense of liberty' (2012) 5, sine loco. 
justice: '[T]he impact of legal change is dependent on wider social and cultural contexts.' 47 The psychological impacts on primary victims of coercive and controlling behaviour is yet to be fully deconstructed or explored by Anglo-Australian courts. This was vividly exemplified in Challen and highlighted previously by Edwards:

Law shapes the social reality such that victims' stories of intimidation, coercion and control are met with response, Yes, yes, but did he hit you'?, and that women come to learn not to talk in court about nonphysical forms of coercion and control, and to understand that it is only physical conduct that is significant. 48

The appellate court in Challen, in a constrained and particularised determination, held that the conviction was unsafe, and should be quashed with a retrial ordered. This was explicitly based on the evidence relating to Sally Challen's personality and mood disorders, and not on the evidence of her husband's controlling behaviour. ${ }^{49}$ Lady Justice Hallett asserted that the court was not persuaded that, had it stood alone, the general theory of coercive control on the facts as presented would have afforded a ground of appeal.50 No view was expressed as to whether Sally Challen was the victim of coercive control, and no view, if she was a victim, on the extent to which it impacted upon her ability to exercise self-control, or her responsibility for her actions. Hallett LJ also re-emphasised that it was important to highlight that coercive control per se is not a defence to murder, but only relevant in the context of other defences, namely self-defence, diminished responsibility and provocation. ${ }^{51}$ It is significant, as such, to posit how primary victims of coercive/controlling behaviour who kill abusive partners may supplant (or otherwise) the three threshold hurdles to any successful provocation defence in the CJA. English

47 Heather Douglas, 'A consideration of the merits of specialised homicide offences and defences for battered women' (2012) 45 Australia and New Zealand Journal of Criminology 367, 378.

48 Edwards (n 31 above) 879.

49 [2019] EWCA Crim. 916. See also Bettinson (n 35 above) 81: '[T]he insistence of the diminished responsibility plea to characterise defendants who kill their abusers as mentally unwell, detracts from the understanding and learning around the use of coercive control in domestic relationships. It works against the operation of the offence which does not require psychiatric injury, but the adverse effect on a person's day-to-day activities. It, therefore, remains an inherently unsuitable defence for women who kill their abusers as a result of coercive or controlling behaviours.'

50 [2019] EWCA Crim 916; Storey (n 33 above).

51 Ibid. Note that in June 2019 the Crown, rather than promulgate a retrial the next month at the Old Bailey, accepted a plea of guilty to manslaughter on grounds of diminished responsibility. Sally Challen was sentenced to nine years and four months - time already served - and consequentially was entitled to be released immediately. 
reforms are comparatively reviewed against the contours of liability in Australia, including the state of Qld. Qld reforms state that, except in circumstances of an exceptional character, the provocation defence does not apply (in the context of a domestic relationship) where the provocation is based on something done by the deceased to end or change the nature of the domestic relationship.

\section{SUBJECTIVE LOSS OF CONTROL: OLD WINE IN NEW BOTTLES}

The Law Commission of England and Wales, as Horder articulates, initially argued in favour of abrogation of any loss of control requirement: '[I]n the Commission's view there should instead be a negative test of whether $\mathrm{D}$ acted out of a considered desire for revenge, and, if not, then the defence would be available in principle.' 52 The CJA does not define what amounts to a loss of control, but self-evidently, a defendant in the factual scenario presented in the Challen case would find it difficult to meet the threshold hurdles, within either old or new provocation law, where any delayed and slow-burn responses are indicated.53 As Bettinson argues, whilst reaction no longer needs to be 'sudden' and in a heat of passion, nonetheless, the longer the temporally individuated delay, and the stronger the evidence of deliberation on the part of any defendant, then deontologically the less likelihood of a successful defence. 54

The loss of control requirement remains opaque, and subject to ad hoc and solipsistic judicial interpretation. Over the course of the last decade, there has been predominant support for review via a powers of ratiocination/individual actor blurred judgement perspective at the time of fatal action, divested from an emotional response/partial loss of capacity conceptualisation of loss of control. This standardisation, however, has not universally been adopted, or always applied

52 Jeremy Horder, Ashworth's Principles of Criminal Law 9th edn (Oxford University Press 2018) 264; Law Commission, Murder, Manslaughter and Infanticide (Law Com No 304, 2006) para 5.18: 'Women's reactions to provocation are less likely to involve a loss of self-control, as such, and more likely to be comprised of a combination of anger, fear, frustration and a sense of desperation. This can make it difficult or impossible for women to satisfy the loss of self-control requirement, even where they otherwise deserve at least a partial defence.'

53 Law Commission, Partial Defences to Murder (Law Com No 290, 2004), para 3.30: '[T]he requirement of a loss of self-control was a judicially invented concept, lacking sharpness or a clear foundation in psychology. It was a valiant, but flawed attempt to encapsulate a key limitation to the defence - that it should not be available to those who kill in considered revenge.' Bettinson (n 35 above) 82-83. 
logically, 55 and the debate that follows illustrates the consequential unpredictability of outcome(s).

In general terms, this limb of the defence has been interpreted in a delimited manner, trammelled via a limitation on the parameters of any provocation defence. 56 This is especially the case where evidence exists of premeditation or the court identifies aspects of 'cold-blooded' killing. In Gurpinar, 57 for example, the appellate court asserted that a trial judge should undertake a much more rigorous evaluation of the evidence before the defence could be left to the jury than had been required under the former law of provocation. ${ }^{58}$ The partial defence is now self-contained within the statutory provisions and, as such, the common law heritage is 'irrelevant'. 59 Sufficient evidence of loss of self-control is now needed for the trial judge to leave the matter for fact-finder consideration; 60 the old law only required 'any evidence at all of a specific provoking event'. 61

It is necessary for the trial judge to consider the weight and quality of the evidence before coming to a conclusion to leave matters to the jury. As McCombe LJ made clear in Barnsdale-Quean,62 'mere speculation without a proper evidential foundation of loss of selfcontrol, is inadequate'. ${ }^{63}$ This requirement, of cogent evidence, beyond the merely fanciful, was repeated by Rafferty LJ in Jewell, ${ }^{64}$ where the appellate court transmogrified a 12-hour cooling-off period between the provoking event and fatal action as the embodiment of premeditation and revenge. The corollary was that the determination not to leave the issue of loss of control to the jury was 'overwhelming', 'inevitable' and 'impregnable':65 '[A]s the appellate court put it in Martin (Jovan), judge's should not "clutter up" a jury's deliberations by inviting them to consider issues which, in truth, did not arise on the evidence.' 66

Simester et al (n 4 above) 413-415. Most recently, in Dawson [2021 EWCA Crim 40 , a very high threshold was set for consideration of loss of self-control.

56 G R Sullivan, 'Anger and excuse: reassessing provocation' (1993) 13 Oxford Journal of Legal Studies 380.

57 Gurpinar and Kojo-Smith [2015] EWCA Crim 178; [2015] 1 WLR 3442.

58 Ibid [12]-[14].

59 Ibid [12]-[13].

60 Ibid [55].

61 Acott [1997] 2 Cr App R 94, 102 (Lord Steyn) who stated that, what was required was 'some evidence of a specific act or words of provocation resulting in a loss of self-control'.

62 [2014] EWCA Crim 1.

63 Ibid [15].

64 [2014] EWCA Crim 414 [27]-[28].

65 Ibid [52].

66 Horder (n 52 above) 265; Martin (Jovan) EWCA Crim 1359 [44] (Davis LJ). 
The appellate court in Jewell, more broadly, viewed loss of selfcontrol through the legal prism of D's powers of ratiocination (or otherwise), and positively endorsed an interpretational construct predicated on impaired judgement and reasoning. ${ }^{67}$ In a similar vein, the Lord Chief Justice in Clinton 68 viewed the validity of loss of selfcontrol as coterminous with the other two limbs of the partial defence, reviewable simultaneously at the time of, or immediately before, the fatal action. ${ }^{69}$ This was extended in Dawes ${ }^{70}$ to adduce consideration of the potential for 'cumulative impact' where antagonism endured over a longer period, but where D was 'shocked' at the time of the final violent blow: 71 '[D] elay between a stimulus and the loss of self-control may be the product of the cumulative impact of events, an especially important explanation for loss of self-control when the defendant and the victim were living together for a long period of time.' 72 The standardisation, however, of loss of control, remains uncertain, and the successful prediction of outcome as likely as tattooing soap bubbles, albeit ratiocination, wrongly it is suggested, holds sway over emotional responses/impaired capacity. ${ }^{73}$

One perspective is that a greater appreciation is needed, as the Challen case exemplifies, of the mixture of emotional responses that apply to the domestic abusee. Mitchell et al suggest that:

[I]nstead of retaining a loss of control as is currently constructed in the rather unsophisticated sense of overtly physical out of control, the law should look at the extent of the defendant's emotional disturbance, and how that disrupted the individual's normal thinking, reasoning and judgment. ${ }^{74}$

A wider perspective of loss of control may arguably be required, integrating detonative 75 partial involuntariness if needed, through a wider kaleidoscopic lens than simply imperfectly justified retributive

67 [2014] EWCA Crim 414 [27].

68 [2012] EWCA Crim 2.

69 Ibid [9].

70 [2013] EWCA Crim 332.

71 Ibid [64]. See also Tony Storey, 'Loss of self-control: the qualifying triggers, self-induced loss of self-control and cumulative impact' (2013) 77 Journal of Criminal Law 189.

72 Horder (n 52 above) 264.

73 Sorial (n 1 above).

74 Barry Mitchell, Ronnie Mackay and Warren Brookbanks, 'Pleading for provoked killers: in defence of Morgan Smith' (2008) 124 Law Quarterly Review 675.

75 'Detonative' is adapted herein in the contextualisation of a sudden and instant violent outburst, often wholly atypical. 
anger or constricted fear of 'serious' violence. ${ }^{76}$ A widened defence based upon semi-voluntariness and partial loss of capacity may arguably extend to actors who kill under conditions of intense grief or sadness, or under other extreme conditions such as intimate breach of trust, and coercive/ controlling behaviour as in the Challen case. ${ }^{77}$ Further consideration is also essential as to when coercive control should lead to a self-defence claim. Extreme reactions are common under other types of emotional conditions, and there is significant psychological literature in support of this proposition. ${ }^{78}$ Emotions provide a connecting narrative between cognition and volition, and, in this perspective, Solomon described emotions as an expression of a personal value system. ${ }^{79}$ The arousal of a particular emotion, and disconnection thereby, may provide an indication that the individual had subjectified prevailing circumstances in a particular manner, and with a subliminal value code: '[E]very emotion ... is a personal ideology, a projection into the future, and a system of hopes and desires, expectations and commitments, and strategies for changing our world.' 80 Emotions are frequently complex phenomena, and, as Dennis has stated, great anger may be mixed with great fear, or with extreme frustration, despair, or shock. ${ }^{81}$ Such a cocktail of mixed emotions resonates to the primary victim of controlling/coercive behaviour, viewed through a prism of patriarchal/intimate terrorism, rather than lessened powers of ratiocination or (ill)considered judgements. 82

76 Reid Griffith Fontaine, 'Adequate (non) provocation and heat of passion as excuse not justification' (2009) 43 University of Michigan Journal of Law Reform 27, 49: '[I]t is not the provocation that mitigates the defendant's culpability and punishment, but the emotionally charged effect that it has ...'.

77 Walklate et al (n 29 above) 118, who contend that 'the effective place for clinical understandings of, and explanations for intimate partner violence, may better lie in expert testimony'; Joshua Dressler, 'Why keep the provocation defence? Some reflections on a difficult subject' (2002) 86 Minnesota Law Review 959.

78 Alan Reilly, 'Loss of control in provocation' [1977] 21 Criminal Law Journal 320; Jeremy Horder, 'Reshaping the subjective element in the provocation defence' (2005) Oxford Journal of Legal Studies 123.

79 Robert C Solomon, The Passions (University of Notre Dame 1976) 'Preface'.

80 Ibid 212; Robert C Solomon, A Passion for Justice (Addison Wesley 1990); Robert C Solomon, 'Philosophy of emotions' in M Lewis and J M Haviland (eds), Handbook of Emotions (Guildford Press 1993).

81 Ian Dennis, 'Editorial' [2008] Criminal Law Review 829; Celia Wells, 'Provocation: the case for abolition' in Barry Mitchell and Andrew Ashworth (eds), Rethinking English Homicide Law (Oxford University Press 2000) 89: '[A]n excuse based on loss of self-control seems to imply an underlying aggression in all of us which is capable of release under certain circumstances.'

82 Victoria Nourse, 'Passions progress: modern law reform and the provocation defense' (1997) 106 Yale Law Journal 1331, 1332-1333: '[T]he defendant's claim to our compassion must put him in a position of normative equality vis-àvis his victim. A strong measure of that equality can be found by asking whether the emotion reflects a wrong that the law would independently punish.' 


\section{THE SEXUAL INFIDELITY EXCLUSION AND LOSS OF SELF-CONTROL}

Sally Challen was presented by the prosecution as a jealous and brooding wife, rather than a coercee who had endured the extreme sexual infelicities of her husband, his continued visits to brothels, and intimate breach of trust including the final discovery that he was seeing another woman.83 The apparent disqualificatory trigger of sexual infidelity in section 55(6)(c) of the CJA presents another potential hurdle to surmount for similar primary victims. It is considered further in the subsequent review of extant laws in Qld, and within the contextualisation of the ambit and parameters of exclusionary triggers more broadly, to ensure comportation with appropriate contemporary standards and societal mores of the day.

Although it is contentious, and dissonant views prevail, 84 it is illogical in the framework of a more nuanced understanding of detonative involuntariness and partial responsibility to universally exclude all and everything said or done that relates to sexual infidelity, as part of a subjectivised loss of self-control fact-finder determination. ${ }^{85}$ The provocative nature of sexual infidelity may operate across a continuum of gradated severity. Emotional excuse needs to be recalibrated to reflect more broadened phenomenological narratives and responses. Killings prompted by proprietorialness (often male), sexual jealousy, envy and premeditation by a cuckolded partner ought to be excluded from denial of responsibility. In equal measure there may be some exceptional cases of 'gross provocation', where sexual infidelity is part of a narrative embracing excessive taunting, extreme sexual humiliation and coercion, and a spontaneous fatal blow ought arguably to be allowed for consideration by fact-finders. ${ }^{86}$ Withey has contended that sexual infidelity is inappositely excluded, when it often coheres with public sympathies and understanding, whilst honour killings, which receive no societal compassion, are still inclusionary under English law. 87 Edwards reiterates the anomaly in such a bifurcation, positing that it is 'strange' how juries can be relied upon to disqualify honour killings, but

83 Bettinson (n 35 above) 82 .

84 Baker and Zhao (n 21 above); and see, in contradistinction, Amanda Clough, 'Sexual infidelity: the exclusion that never was' (2012) 76 Journal of Criminal Law 382, 384 who states: '[T] o view any other circumstances without shedding light on infidelity claims would give us a very blurred picture of what happened.' Amanda Clough, 'Battered women: loss of control and lost opportunities' (2016) 80 Journal of International and Comparative Law 279.

86 Douglas Brown, 'Disentangling concessions to human frailty: making sense of Anglo-American provocation doctrine through comparative study' (2007) 39 New York University Journal of International Law and Politics 675.

87 Carol Withey, 'Loss of control, loss of opportunity' [2011] Criminal Law Review 263. 
not demarcated cases of sexual infidelity. 88 Turner compartmentalises the exclusion within a politically motivated and sentencing framework:

What the government is proposing will not save any lives, because a sudden loss of self-control cannot be influenced by the new law. It will, however, lead to many more ... [s]erving extremely long sentences for crimes of passion that they could not prevent themselves from committing. 89

Ignoring the emotional excuse narrative attached to extreme illustrations of sexual humiliation, taunting, coercion and breach of trust, and disregarding the consequential partial loss of control, is to separate law from reality and phenomenological triggers. Extreme emotional distress as part of subjectivised detonative involuntariness should, as Reilly has intimated, form a central part of the moral capacity inquiry: '[T] he assessment of the gravity of the provocation is the outlet for the telling of the history. The narrative of how the loss of control transpired begs the question of why.' 90 It is inapposite to solely focus upon the precise moment that the fatal blow was struck, and a broader evaluative context is required, otherwise it 'diminishes the power of the preceding narrative, bending the climax to the existence or not of the nebulous concept of a loss of self-control'. 91

The divorce from moral capacity is apparent in the extreme breach of trust illustration that Horder has presented. $92 \mathrm{D}$ loses self-control and kills $\mathrm{V}$ when $\mathrm{V}$ (D's husband) admits having had long-standing affairs with (and made pregnant) each of D's three 16 to 18-year-old daughters by a previous marriage. Horder posits that this scenario presents a series of intractable questions, and multifarious difficulties, under exclusionary extant law:

May the jury take into account the girl's pregnancies that are the result of the infidelity in that they are offspring born and related to D? Further, suppose V started an affair with one of the daughters before meeting D, would $\mathrm{D}$ be able to rely on evidence of that affair given that there was no obligation of fidelity to D at that stage? How far into the question whether the affair started before V met $\mathrm{D}$ should the court be prepared to go? 93

88 Edwards (n 9 above) 230.

89 J Turner, 'Provocation and infidelity' (1963) 127 Justice of the Peace and Local Government Review 745.

90 Reilly (n 78 above) 331-332.

91 Ibid.

92 Note that the postulation is repeated verbatim from Horder's memorandum submitted to the Commons at the committee stage of the CJA: House of Commons, Coroners and Justice Bill Committee, Memorandum submitted by Jeremy Horder, 3 February 2009, CJ 01. Ibid. 
By judicial sleight of hand, albeit counterfactually and contrary to legislative import, the appellate court in Clinton, 94 post-CJA 2009 reform, has acknowledged a wider inclusionary contextualisation for sexual infidelity killings. The aim of the determination was to 'prevent injustice' and 'absurdity of result'.95 It is comparatively reviewed subsequently in terms of recent developments in Qld. A legislative effort to exclude the provocation defence in Qld in the context of sexual infidelity and in circumstances where women appear to have changed or left the relationship has been evaluated in two very recent important cases of Peniamina ${ }^{96}$ and Pilcher, 97 effecting unanticipated and inconsistent extant laws.

In Clinton, 98 the defendant was devastated when his wife of 16 years left him and their two children to begin a trial separation. The killing occurred a few weeks after the separation. In the interim period, Clinton had accessed his wife's Facebook account which revealed a new relationship, and he found sexually explicit photographs which confirmed the affair. The victim had also informed him that she had engaged in sexual intercourse with five different men, providing graphic details, and taunted him over accessing a suicide website, and stated that he would have full responsibility for all childcare arrangements. D picked up a wooden baton and struck $\mathrm{V}$ repeatedly, before strangling her with a ligature, and posted pictures of her dead body to her new partner. The appellate court determined that it was a misdirection to withdraw the loss of self-control defence from fact-finder consideration predicated on V's confession of sexual infidelity, as it 'should' be relevant to the totality of matters relied on as a qualifying trigger. A retrial was ordered, but Clinton pleaded guilty to murder in advance of the retrial commencing and was sentenced to imprisonment for not less than 26 years.

Sexual infidelity, evidenced throughout the narrative in Challen, and as a final provoking stimuli, remains excluded from consideration post-Clinton when it arises as the only qualifying trigger. In other cases, it may potentially be evaluated to provide an integral contextualisation to events, determining whether circumstances are grave and to establish a justifiable sense of being seriously wronged. ${ }^{99}$ A mystical divining-rod is needed to help direct a befuddled jury in this regard, as the appellate court itself identified in Clinton:

\footnotetext{
94 [2012] EWCA Crim 2.

95 Ibid [39].

96 [2019] QCA 273.

97 [2020] QCA 8.

98 [2012] EWCA Crim 2.

99 Simester et al (n 4 above) 419.
} 
[T] heir will be occasions when the jury would be both disregarding and considering the same evidence. That is, to put it neutrally, counter-intuitive. 100

More broadly, and directly applicable to Sally Challen and other coercee killers, the underlying narrative of emotional excuse, and relational construct in which the detonative partial loss of capacity occurred, could perhaps be addressed in a recalibrated loss of selfcontrol framework. ${ }^{101}$ Further review, beyond the strictures of current provocation law, should indicate a preference for a new selfpreservation defence, as considered later in this article, albeit in limited situations. The extant requirement for subjectivised loss of self-control at the time of the fatal action ought to be abrogated: it is not about powers of ratiocination and judgement, but rather extreme emotional response and reduced capacity: 'without attention to the batterer's use of coercion, pressure, influence or threat of force to the degree that these tactics interfere with a victim's volition, courts hear only parts of victims' stories'. ${ }^{102}$ It may be illogical to have a blanket exclusion for all standardisations of sexual infidelity, and no particularised pathway for coercive/controlling behaviour that coalesces as a partial defence to murder. A wider and more coarse-grained response is needed, which embraces more delineated contextualisations of excuse. ${ }^{103}$ The effect would be to reduce murder to manslaughter where the accused committed the act under the influence of extreme emotional distress for which there is a reasonable explanation or excuse, obviating direct reference to subjectivised loss of self-control.104 The benefit, as Reilly has identified, is that the courts would not feel obliged to create taxonomies of emotional conditions associated only with a loss of self-control and would avoid parlous psychological assessments of this issue alone. ${ }^{105}$ The broader consideration of extreme emotional distress as an excuse, possibly subject to semi-voluntary conduct and disinhibition, could allow for fairer labelling and disposal. It is integral

100 [2012] EWCA Crim 2 [32].

101 Griffith Fontaine (n 76) 43, who asserts: '[I]t is because the reactive violence, though wrongful, is understandable, that the reactor is partially excused. The understanding lies in the acknowledgement that, given the circumstances, a similarly placed individual would likely experience emotional disturbance similar to that of the defendant's, and that such an emotionally aroused state can .... Limit one's self-control'.

102 Tamara I Kuenmen, 'Analysing the impact of coercion on domestic violence victims: how much is too much?' (2013) 22 Berkeley Journal of Gender, Law and Justice 2.

103 Suzanne Uniacke, 'Emotional excuses' (2007) 26 Law and Philosophy 95 and Sanford H Kadish, 'Excusing crime' (1987) 75 California Law Review 257.

104 Withey (n 6 above); Horder (n 78 above); Brown (n 86 above); Dressler (n 77 above).

105 Reilly (n 78 above) 329-332. 
in cases of controlling/coercive behaviour such as Sally Challen, to battered women who killed in Ahluwahlia,106 Thornton,107 and Humphreys, 108 and as part of the legal hinterland attached to emotional trauma more broadly, including mercy killings. ${ }^{109}$

\section{FEAR OF SERIOUS VIOLENCE AND DETONATIVE SELF-PRESERVATION AS A PARTIAL DEFENCE}

The old provocation law was untrammelled in that the adduction of loss of control simply had to occur from 'any' specific provoking event. The CJA 2009 reforms, however, mandate a more restrictive template where derivatively only two qualifying triggers are operative - fear of serious violence directed by $\mathrm{V}$ against $\mathrm{D}$ or another, or alternatively imperfectly justified anger (gross provocation). The former standardisation, unfortunately, has not proved the anticipated panacea to cathartically cure the ills attached to unfair disposals of battered women abusive partner killings. ${ }^{110}$ The fear trigger is wholly exclusionary where the threats are not of immediate physical injury, but rather psychological harm.111 As presented in Challen, the anticipatory threat was not of instant physical violence, but the slowdrip incremental effect of desensitising/dehumanising conduct creating a cycle of control.112 A fundamentally different modus operandi of fear was constructed, contextualised as bending to his will: individual functionality was precluded. As Wells states, an alternative paradigm exists, beyond the stereotypical imagery of 'one to one (man to man) violence' and threats: '[D]omestic violence is outwith the paradigm where it occurs it is chronic, cyclical and often inescapable.'113 The challenge remains, often insurmountable, for the domestic abusee in fear of harm(s) to convey her psychological perception of experiencing

106 [1992] 4 All ER 889.

107 Thornton (No 2) [1996] 2 All ER 1023.

108 [1995] 4 All ER 1008.

109 Jonathan Rogers, 'Prosecutorial policies, prosecutorial systems and the Purdy litigation' [2010] Criminal Law Review 543. In suggesting this, however, we do not discount the need for an expanded role for self-defence in some cases where abused women kill their abuser.

110 Edwards (n 28 above) 95: '[T]his new provision reflects a moral and conceptual shift and retreat from Duffy in that the past violent conduct of the deceased becomes foregrounded in a centrifugal aspect of the relevant factual and evidential narrative in evaluating whether there exists evidence of a claim of fear of serious violence.'

111 Edwards (n 25 above) 79 who asserts: '[W]omen will still be required to lose selfcontrol in the conventional way and her fear will not be understood.'

112 Bettinson (n 35 above) 83.

113 Celia Wells, 'Battered woman syndrome and defences to homicide: where now?' (1994) 14 Legal Studies 266, 272. 
immediate 'serious' violence. A particularly high threshold for factfinders' determination where the final triggering act does not meet the particularisation of 'serious' violence, or an 'imminent' threat, essential constituent elements within an alternative self-defence criteria:114

[T] he last act preceding the killing of the abusive partner may be the sound of keys turning in the lock, or a car parking in the driveway, hardly an act of violence let alone serious violence. ${ }^{115}$

A high bar has been set for the self-defence effectuation, consequentially making it more difficult for women to succeed with the fear trigger: '[L]ast straw, frayed elastic arguments may be excluded.'116 Edwards has made clear that, whilst the legislative reforms were predicated upon the development of a new compartmentalisation of cumulative fear, 'fear sharpening fear for the future',117 aspirations are deleteriously compromised by the serious violence template, deontologically iterating a proportionate response inculcation, or within a proportionate continuum inappositely synchronising fear, reaction and response. 118 Gender imbalances over modus operandi of killing methods per se linked to physicality, continue to refract disadvantageously for disposal of women defendants: women are more likely to use weapons than men, and this has significant implications at both prosecutorial and sentencing stages. ${ }^{119}$ In violent altercations, as Wake adumbrates, the use of bodily force is considered a mitigating factor, whereas the use of weapons in like circumstances is regarded as an aggravating feature. ${ }^{120}$ A further layer of difficulty applies to the fear trigger, in that a subjectivised loss of control must still be presented at the time of the fatal action, with attendant inconsistencies appurtenant thereto: '[T]he behavioural response of a person in fear will almost certainly

114 Nicola Wake, 'Human trafficking and modern day slavery: when victims kill' [2017] Criminal Law Review 658; Wake (n 29 above); Clough (n 85 above).

115 Edwards (n 25 above) 93. See also Mitchell et al (n 74) 680, who recognise that the outward manifestation of fear is likely to be the antithesis of anger's externality: '[F]ear ... will probably result in what is overtly less frantic, more deliberate behaviour.'

116 Ibid 92-93.

117 Edwards (n 30 above) 468, also stating: '[T]he "serious violence" requirement contemplates something approximating a proportionate response, or at least inhabits a position on the proportionality continuum.'

118 Clough (n 85 above) 285, who contends that: 'Proportionality is equally problematic with battered women often choosing to arm themselves rather than face their attacker with bare fists. This often makes the violence a battered woman uses to defend herself seem excessive when she is really resorting to a form of violent self-help.'; Wake (n 29 above).

119 Wake (n 31 above).

120 Wake (n 30 above) 437, contending: '[A] discrepancy in physical strength may require the abused $\mathrm{D}$ to arm herself thereby rendering it more likely that such conduct would be considered excessive.' 
place the terrified woman outside the jurisdiction of anger's expression, its typological template of loss of self-control.'121

A new type of psychological partial defence is required, predicated on self-preservation, detonative loss of capacity and extreme emotional response. ${ }^{122}$ This de novo via media defence should be complemented by social framework evidence and mandatory jury directions, considered subsequently, similar to those operating in Victoria (Australia) albeit in an alternative self-defence template.123 A newly structured interlocutory appeal procedure would provide defendants with an opportunity to challenge the judge's refusal to admit the defence prior to trial, thereby preventing unnecessary appellate court litigation. This would recognise the challenge, in part, that Wells presents that coercive/controlling behaviour (domestic abuse) typified in Challen does not simply infract an individual's physical integrity, 'it is an instrument of psychological and emotional control'.124 A requirement is that the defendant acted in extreme emotional response, integrating dissonant categorisations of abusive behaviour, incorporating controlling coercive conduct. As such, the term 'abuse' should be broadly construed to include psychological and sexual harm, and coercive/controlling behaviour, in addition to 'serious' physical violence. ${ }^{125}$ The victim of abuse's response to the predominant aggressor in future cases should not necessarily follow primordially from the severity of the last act of abuse but, as Clough contends, 126 should flow from the cumulative perceptions of the severity of the threat posed, articulated within the penumbra of social framework evidence and particularised juror directions. ${ }^{127}$

In cases of prolonged and systematic abuse, where D kills an abuser, and self-defence, as an all or nothing affirmative defence is unavailable (because imminency of threat/proportionality, reasonable force criteria are unsatisfied) a de novo alternative partial defence is needed, plus further changes to self-defence. ${ }^{128}$ Reflective consideration

121 Edwards (n 25 above) 92.

122 See Carline and Easteal (n 44 above) 140.

123 Jury Directions Act 2015 (Vic).

124 Wells (n 113) 272.

125 Ana Speed, Callum Thomson and Kayleigh Richardson, 'Stay home, stay safe, save lives? An analysis of the impact of Covid-19 on the ability of victims of gender based violence to access justice' (2020) 84(6) Journal of Criminal Law 539-572; and see enactment of domestic abuse legislation in England and Wales.

126 Clough (n 85 above) 284.

127 Wake (n 31 above) 298; Wake (n 30 above) 439.

128 Amanda Clough, 'Honour killings, partial defences and the exclusionary conduct model' (2016) 80 Journal of Criminal Law 177; Jeremy Horder and Kate FitzGibbon, 'When sexual infidelity triggers murder: examining the impact of homicide law reform on judicial attitudes in sentencing' (2015) 74 Criminal Law Journal 307. 
of the Challen case ought to promulgate a new psychological selfpreservation partial defence, 129 especially as no political will exists in England to realign and recalibrate either loss of control or diminished responsibility: '[T]he fear descriptors must be cast so as to reflect the multifacedness of women's experience of, and reaction to abuse and its threats.' 130

A partial defence of detonative self-preservation avoids the stigmatic murder label; it may influence charging practices by encouraging guilty pleas, thereby avoiding unnecessary trials, or by encouraging a trial where self-defence might apply on grounds that the partial defence represents a safety net. ${ }^{131}$ It sends a signal, as Wake contends in a different context, to sentencing judges and society generally regarding culpability levels. 132 The extant fear trigger fails to properly accommodate the very different manifestations of attitudinal fear and the overarching requirement of loss of self-control: '[E]xperts will be needed to elaborate on the fluidity and polysemicity of the signs and manifestations of fear.'133 The absence of any proportionality and imminency requirements is justified on the predicate that detonative psychological (and physical) self-preservation is a partial rather than a complete defence. In cases where D claims to have a particular belief as regards the circumstances, as presented in the new evidence in Challen, the reasonableness or otherwise of that belief is relevant to the question of whether D genuinely held it, but there must be an intelligible basis for the belief. ${ }^{134}$ Importantly, the defence will not automatically apply where self-defence fails on grounds of lack of reasonableness/ imminency, as otherwise it would be overbroad in ambit and subject to similar criticisms that were levelled at the defensive homicide defence in Victoria, prior to abrogation. ${ }^{135}$ It would facilitate an understanding of Challen's experience and other similar abusees. ${ }^{136}$

129 Neil Cobb and Anna Gausden, 'Feminism, "typical” women and losing control' in Reed and Bohlander (n 21 above) 97.

130 Edwards (n 25 above) 92.

131 Wake (n 31 above) 298.

132 Clough (n 85 above) 286.

133 Edwards (n 28 above) 83.

134 Bettinson (n 35 above) 83, who comments that: 'Even with an appreciation of coercive control, it seems unlikely that the court would construe a fear of serious violence to extend to Challen's fear of separation from her abuser.'

135 Brenda R Midsom, 'Degrees of blameworthiness in culpable homicide' (2015) 6 New Zealand Law Journal 220. See also Kate Fitz-Gibbon, Homicide Law Reform, Gender and the Provocation Defense: A Comparative Perspective (Palgrave MacMillan 2014).

136 Barbara Midsom, 'Coercive control and criminal responsibility: victims who kill their abusers’ (2016) 27 Criminal Law Forum 417. 


\section{COERCIVE OR CONTROLLING BEHAVIOUR AS A QUALIFYING TRIGGER: NEW JUROR DIRECTIONS}

An alternative route for consideration, beyond fear of serious violence, applies more directly in similar cases to Challen. The loss of self-control within section 55(4)(a) of the CJA 2009 will also have a qualifying trigger if it was attributable to something done or said or both which constituted circumstances of an extremely grave character and caused D to have a justifiable sense of being seriously wronged. The Government, in setting this qualifying trigger as a preliminary filter device in the CJA 2009, again raised the discretionary bar in an exclusionary fashion. The prescribed aspiration was to 'raise the threshold' so that words and conduct would constitute a defence 'only in exceptional circumstances'.137 A byproduct is that defendants in the older common law types of 'provocative' situations, presented in Doughty 138 (stressed parent of persistently crying child), or Dryden 139 (obsessional home owner embroiled in planning dispute), or Baillie ${ }^{140}$ (affronted parent of drug-dealing son), and presumptively Morhall141 (glue-sniffing addiction), are no longer within the operational purview of the defence as falling far below the threshold standards(s) of 'justified anger'. That said, coercive/controlling behaviour and domestic abuse fit a wholly different categorisation, and expert testimony in Challen, and other similar cases, could adventitiously articulate the applicability of circumstances of an extremely grave nature. This would transmute our understanding of Challen's case beyond that of defence representation as a vengeful spouse responding simply to discovery of her husband entering a new relationship. ${ }^{142}$ As Simester et al have articulated, whether the circumstances were extremely grave, and D was seriously wronged and whether D's sense of grievance was justifiable, are to be evaluated normatively by fact-finders as moral arbiters. ${ }^{143}$

The focus, within this qualifying trigger, is on the reasonableness or otherwise of the coercee's actions set against provoking conduct, rather than their psychological trauma/extreme emotional disturbance at the time of the fatal blow: '[T]he effect is to transmute battered women syndrome from locating women's motive for conduct within an abnormal state of mind to situating it within a framework of reasonableness, necessity and duress.' 144 The wrongfulness of the abuse the coercee

137 HC Deb 3 February 2009, col 8 (Maria Eagle, Parliamentary Under-Secretary of State for Justice).

138 (1986) 83 Cr App R 319.

139 [1995] 4 All ER 987.

140 [1995] 2 Cr App R 31.

141 [1996] 1 AC 90.

142 Bettinson (n 35 above) 83-84.

143 Simester et al (n 4 above) 417-418.

144 Edwards (n 9 above) 235. 
is suffering must, as Herring states, be properly understood. ${ }^{145}$ There is a need to adopt in English law a reconstituted set of jury directions. The challenge, as Bettinson has outlined, is to explain the dynamics of coercive/controlling behaviour within the contemporisation of the imperfectly justified anger qualifying trigger: problematic where 'the things said or done involve psychological tactics'.146

A reform route for English law is presented by legislative changes adopted by Victoria in Australia, within the purview of the Jury Directions Act 2015.147 These directions may be adapted to comport with coercive/ controlling behaviour and domestic abuse as a partial defence, rather than self-defence as an all or nothing standardisation, and within a widened family violence framework. ${ }^{148}$ Where requested by the defence, and where relevant; the trial judge must inform the jury that coercive/ controlling behaviour is in issue and that evidence of family violence (physical, sexual or psychological abuse) is to be considered and may be relevant in determining whether $\mathrm{D}$ acted under a loss of self-control.149 It is possible for a trial judge to decline such a request, but only where there are good reasons to do so, for example, unnecessarily demeaning the victim. The following matters may be included in the direction.

- That family violence:

- is not limited to physical abuse and may include sexual abuse and psychological abuse;

- may involve intimidation, harassment and threats of abuse;

- may consist of a single act; and

- may consist of separate acts that form part of a pattern of behaviour which can amount to abuse even though some or all of those acts may, where viewed in isolation, appear to be minor or trivial.

- It is not uncommon for a person who has been subjected to family violence:

- to stay with an abusive partner after the onset of family violence or to leave and then return to the partner; and

145 Herring (n 26 above) 66-67.

146 Bettinson (n 35 above) 84.

147 Jury Directions Act 2015 (Vic), ss 55-60. See also Crimes Act 1958 (Vic), ss 322J and $322 \mathrm{M}(2)$ for the basis of these provisions.

148 Note that the Crimes Amendment (Abolition of Defensive Homicide) Act 2014 abolished the Australian state of Victoria's only general partial defence of defensive homicide and replaced the existing statutory self-defence in murder/ manslaughter provisions and general common law self-defence rules with a single test. In the absence of a partial self-defence, self-defence becomes an all or nothing claim, where a successful plea results in an outright acquittal, and an unsuccessful plea results in conviction for the offence charged.

149 Wake (n 29 above) 156-158. 
- not to report family violence to police or seek assistance to stop family violence. 150

These jury directions could similarly be amended to capture the broader category of primary victim which the proposed reforms seek to accommodate. The jury directions are designed to complement the social framework evidence provisions in Victoria, considered below, and to assist in counteracting myths surrounding the impact of abuse, and they are designedly flexible in order to ensure that the trial judge can tailor individual directions to the specific facts of the case. ${ }^{151}$

It is essential to collectively transform our presuppositions and how 'reasonableness' of action is evaluated/directed in the Challen case, and domestic abuser killings more broadly. The trial judge in the CJA 2009 reforms has the authority to reject a loss of control claim on the predicate that no jury properly directed could reasonably conclude that sufficient evidence prevails for the defence to apply. ${ }^{152}$ A new interlocutory appeal procedure ought adventitiously to be adopted, mirroring Victoria, whereby the grounds for the plea would be considered at a pre-trial hearing under case management procedures. The implementation of an interlocutory appeal route, as Wake articulates in a different contextualisation, 153 would mean that a trial judge's decision could be challenged (only) before trial, thereby preventing unnecessary appellate court litigation. ${ }^{154}$ In cases where family violence is present, then juror directions, as above, and adapted from Victoria's promulgations, ought to be mandatory, ensuring consistency rather than solipsistic and incremental counsel requests: '[P]roperly understood domestic abuse should readily be regarded as a very serious wrong, where coercive control is a feature.' 155 Further explanation of the interposition of gross provocation, provoker wrongdoing and interpretation of 'warranted excuse' is provided in our review of recent developments in NSW.156

150 Nicola Wake and Alan Reed, 'Reconceptualising the contours of self-defence in the context of vulnerable offenders: a response to the New Zealand Law Commission' (2016) 3 Journal of International and Comparative Law 195-247 .

151 Ibid.

152 CJA, s 54(6); Reed and Wake (n 21 above) 129-133.

153 Wake (n 29 above) 158.

154 Reed and Wake (n 21 above) 130-131.

155 Herring (n 26 above) 66-67.

156 Susan D Rozelle, 'Controlling passion adultery and the provocation defense' (2005) 37 Rutgers Law Journal 197, 226-227, who contends that a provocation defence ought to be available only where the law actually permits the victim of an attack to protect herself through use of force, but the defendant uses too much force and kills the provoker; and see Roni Rosenberg, 'A new rationale for the doctrine of provocation: applications to cases of killing an unfaithful spouse' (2019) 37 Columbia Journal of Gender and the Law 220. 


\section{THE NORMATIVE STANDARDISATION OF LOSS OF CONTROL AND SOCIAL FRAMEWORK EVIDENCE}

Finally, the defendant's loss of control must be judged by reference to a normative standard. The circumstances of the defendant are excluded from fact-finder evaluation where the 'only' relevance is that they bear upon a general capacity for normal tolerance and selfrestraint. This layers an element of flexibility into the standardisation, and illustratively the Lord Chief Justice stated in Asmelash,157 albeit obiter, that alcoholism may be a relevant consideration for the purposes of the objective test where $\mathrm{D}$ is mercilessly taunted about the condition to the extent it is relevant in it cohering to the gravity of the individual's provocation. ${ }^{158}$ The appellate court, however, in Rejmanski; Gassman,159 in conjoined appeals engaging posttraumatic stress disorder and an emotionally unstable personality disorder, constrained the cognisance of such mental disorders where they simply reduced D's 'general' capacity for tolerance or restraint. ${ }^{160}$ In Challen, and similar future coercive/controlling behaviour cases, the defendant will be judged against a standardisation of normative restraint, but crucially the relevance of the particularised background of controlling/coercive 'circumstances' needs to be provided in expert testimony to the jury. ${ }^{161}$

A widened contextualisation and understanding of the abusive relationship, desensitising/dehumanising and overarching coercive circumstances needs to be presented to the jury, beneficially adapting Social Framework Evidence provisions in Victoria. 162 The initial utility of expert testimony of battered woman syndrome, in general, in a forensic context, lay in explaining the circumstances of the abuse. However, erroneous, albeit benevolent, applications meant, as Wake has stated, 163 that 'syndromisation' of the term was frequently invoked as a relevant and defining characteristic of the 'reasonable

157 [2013] EWCA Crim 157.

158 Ibid [25]. See also Ruddelle [2020] NZHC 1983, wherein in a New Zealand case the sentencing judge examined the interaction of alcohol and coercive control.

159 [2017] EWCA Crim 2061.

160 Note that in Dawes [2013] EWCA Crim 322 the appellate court established some threshold parameters: 'For the individual with normal capacity of self-restraint and tolerance, unless the circumstances are extremely grave, normal irritation, and even serious anger do not often cross the threshold into loss of control.'

161 Bettinson (n 35 above) 84; I Leigh; 'Two new partial defences to murder' (2010) Criminal Law and Justice Weekly 53.

162 Wake (n 29 above); Crimes Act 1958 (Vic), s 322J, and more recently see changes in Western Australian law: s 39 of the Evidence Act 1906 (WA).

163 Wake (n 30 above) 437. 
person' amorphous test. 164 The connotations associated with the syndromisation, and potential for misapplication, render its future utility in depicting the nature of dissonant domestic abuse doubtful. More appropriate is adaptation of a broadened, gender-neutral and non-stigmatising provision of Social Framework Evidence: '[U]nfortunately criminal law frameworks struggle to capture the real nature of the harm. Instead the focus is on isolated physical injuries that can be seen where context is disregarded.'165

Social Framework Evidence, as a derogation from Victoria's provisions, engenders a departure from a primordial focus on the physical impact of the abuse and highlights the relevance of the dynamics of the relationship, any psychological harm(s), strategic responses designed to resist, avoid or escape the violence, control and coercion, and the ramifications of these efforts, in addition to social and economic factors pertinent to the abuse. ${ }^{166}$ A departure from the pathologisation of the primary victim is adduced, facilitates an explanation and understanding of Sally Challen's response to her circumstances and experience and provides an appropriate route for English law reform development. ${ }^{167}$ The following evidence may be admissible in addressing liability:

a) the history of the relationship between the person and the family member, including abuse by the family member towards the person, or by the person towards the family member, or by the family member or the person in relation to any other family member;

b) the cumulative effect, including psychological effect on the person or family member of that abuse;

c) social, cultural or economic factors that impact on the person or a family member who has been affected by family violence;

d) the general nature and dynamic of relationships affected by family abuse, including the possible consequences of separation from the abuser;

e) the psychological effect of violence on people who are or have been in a relationship affected by abuse; and

f) social or economic factors that impact on people who are or have been in a relationship affected by abuse. ${ }^{168}$

164 Alan Reed and Nicola Wake, 'Anglo-American perspectives on partial defences: something, old, something borrowed, and something new' in Reed and Bohlander (n 21 above) 183.

165 Bettinson (n 27 above) 167.

166 Wake and Reed (n 150 above).

167 Thomas Crofts and Danielle Tyson, 'Homicide law reform in Australia: improving access to defences for women who kill their abusers' (2013) 30 Monash University Law Review 864.

168 Asher Flynn and Kate Fitz-Gibbon, 'Bargaining with defensive homicide, examining Victoria's secretive plea-bargaining system post law reform' (2011) 35 Melbourne University Law Review 905. 
The blameworthiness of coerced vulnerable defendants needs proper and fair re-evaluation. Our attention now turns to fuller consideration of Australian precepts on loss of control and developments over the course of the last decade.

\section{AUSTRALIA'S REFORMS}

Similar to England and Wales, debates about provocation reform have continued in Australia. In the Australian context, scholars have also identified concerns with the provocation defence, in particular arguing it operated to protect and excuse male anger, jealousy and control over women. ${ }^{169}$ While on its face the provocation defence is neutral, Ramsey points out that it:

... encourages a stereotype of men as hot-blooded, impulsive, and unable to control their violent urges. This is especially troubling because an alternate construction of the facts often suggests a premeditated murder arising from the defendant's outrage at his failure to dominate his intimate partner over a long period of time. ${ }^{170}$

Similarly, in her consideration of the provocation defence, Morgan found that it appeared to accept that it is 'provocative' for women to leave their partners, at least when they 'flaunt' their new relationship. ${ }^{171}$ Morgan suggested that fatal responses to women's choices about the relationship could be understood as attempts by male partners to 'control'172 their female partner.

At the same time, women who feared for their life and killed their abuser in response to a continuing experience of domestic and family violence and control over a long period often relied on the defence of provocation because they struggled to fit their experience into the requirements of self-defence.173 As McMahon notes, the traditional requirements for self-defence including imminent threat, proportionality of response and retreat were 'derived from one-off, sudden encounters between males of (presumed) equal strength'.174

169 Fitz-Gibbon (n 135 above); Danielle Tyson, Sex, Culpability and the Defence of Provocation (Routledge 2013).

170 Carolyn Ramsey, 'Provoking change: comparative insights on feminist homicide reform' (2010) 100 Journal of Criminal law and Criminology 33-108, 59.

171 Jenny Morgan, Who Kills Whom and Why: Looking Beyond the Legal Categories 7 (Victorian Law Reform Commission Occasional Paper, 2002) 39. See also Adrian Howe, 'Reforming provocation (more or less)' (1999) 12 Australian Feminist Law Journal 127, 130.

172 Morgan (n 171 above).

173 Ramsey (n 170 above) 60; Morgan (n 171 above) 41-43.

174 Marilyn McMahon, 'Homicide, self-defence and the (inchoate) criminology of battered women' (2013) 37 Criminal Law Journal 79, 81-82. 
Over the past 30 years or more, research in the social sciences has shown that domestic violence is often underpinned by coercive and controlling tactics, developed by the abuser frequently over a long period of time and targeted to the individual victim. ${ }^{175}$ This research has also showed that, for women in coercive and controlling relationships, separation was dangerous because it challenged the abuser's control. 176 Often the coercive and controlling abuser isolated the victim from those who might be able to help her, and so escape was both difficult, or impossible, and certainly dangerous. ${ }^{177}$ In some Australian cases, abused women have relied on the provocation defence, resulting from their fear of their abuser, rather than anger, and armed themselves with whatever is to hand, killing their abuser when he was unarmed, his back was turned or he was asleep. ${ }^{178}$ Access to self- defence in such cases was difficult because of the requirements of imminence, proportionality and retreat.

With these concerns in mind, Australian jurisdictions have experimented with a variety of approaches to reform homicide defences over the past 20 years. In this section, we focus on reforms to the provocation defence. Australia's constitutional arrangements result in homicide largely being a matter for the states and territories to regulate, 179 and, as a result, the partial provocation defence, and the question of how loss of self-control is dealt with in the context of homicide, is managed differently in each of the eight Australian jurisdictions. Only in South Australia 180 does the common law approach to provocation continue to apply. In recent times Tasmania

175 Stark (n 45 above).

176 Martha Mahoney, 'Legal images of battered women: redefining the issue of separation' (1991) 90 Michigan Law Review 1; Walter S DeKeseredy, Molly Dragiewicz and Martin D Schwartz, Abusive Endings: Separation and Divorce Violence against Women (University of California Press 2017).

177 Australia's National Research Organisation for Women's Safety (ANROWS), Women Who Kill Abusive Partners: Understandings of Intimate Partner Violence in the Context of Self-defence (ANROWS 2019) 17.

178 Chhay $v R$ (1994) 72 A Crim R 1; Van den Hoek $v R$ (1986) 161 CLR 158. See also Rebecca Bradfield, The Treatment of Women Who Kill their Violent Male Partners within the Australian Criminal Justice System (Unpublished PhD Thesis, University of Tasmania, 2002): in the case of all 22 women who killed their partners and successfully argued provocation, there was a history of prior physical violence.

179 Arlie Loughnan, Self, Others and the State: Relations of Criminal Responsibility (Cambridge University Press 2019) 40-41.

180 Lindsay $v$ The Queen [2015] HCA 16. See also Kent Blore, 'Lindsay v The Queen: homicide and the ordinary person at the juncture of race and sexuality' (2018) 39 Adelaide Law Review 159-201. 
(in 2003), 181 Victoria (in 2005) 182 and Western Australia (WA) (in 2008) 183 have abolished provocation as a partial defence to murder, ultimately leaving the loss of self-control as a matter for sentencing. ${ }^{184}$ Notably, in Victoria ${ }^{185}$ and WA ${ }^{186}$ changes to the defence of selfdefence and evidence laws were introduced alongside the abolition of the provocation defence in efforts to expand the application of selfdefence to circumstances where battered women kill their abusive partner. In at least three states, Victoria, NSW and Qld, the most recent decision to abolish or reform the partial defence was underpinned by a specific case where a man had violently killed his intimate partner and successfully claimed provocation. These cases shocked the community and galvanised activists and politicians to implement change.187 While NSW (in 2014), 188 Qld (in $2010^{189}$ and then again in 2017), 190 Northern Territory (NT) (in 2006) 191 and Australian Capital Territory (ACT) (in 1990)192 have retained the partial defence of provocation, each jurisdiction has reformed its limits and application differently. To add to the complexity and patchwork of approaches in Australia, in

181 Criminal Amendment (Abolition of Defence of Provocation) Act 2003 (Tas), repealed s 160 of the Criminal Code Act 1924 (Tas). The Criminal Code Amendment (Life Prisoners and Dangerous Criminals) Act 1994 (Tas) amended s 158 of the Criminal Code Act 1924 (Tas), removing the mandatory life sentence for murder, replacing it with a maximum life sentence.

182 Crimes (Homicide) Act 2005 (Vic). See generally Victorian Law Reform Commission, Defences to Homicide (Report No 94, October 2004). Victoria abolished mandatory life imprisonment for murder in 1986, Crimes (Amendment) Act 1986 (Vic).

183 Criminal Law Amendment (Homicide) Act 2008 (WA). This legislation also reformed the penalty for murder from mandatory to presumptive life imprisonment: see Criminal Code Compilation Act 1913 (WA), s 279(4). For background to the reforms, see Western Australia Law Reform Commission, Final Report: Review of the Law of Homicide (Report No 97, September 2007).

184 Ramsey (n 170 above) 33.

185 Bronwyn Naylor and Daniel Tyson, 'Reforming defences to homicide in Victoria: another attempt to address the gender question' (2017) 6(3) International Journal for Crime, Justice and Social Democracy 75; s 322J of the Crimes Act 1958 (Vic).

186 Stella Tarrant, 'Self defence against intimate partner violence: let's do the work to see it' (2018) 43(1) University of Western Australia Law Review 196, and Evidence Act 1906 (WA), s 39.

$187 R v$ Ramage [2004] VSC 508; Singh $v R$ [2012] NSWSC 637; $R v$ Sebo, ex parte Attorney General [2007] QCA 426.

188 Crimes Amendment (Provocation) Act 2014 (No 13) (NSW).

189 Criminal Code and Other Legislation Amendment Bill 2010 (Qld), cl 5 amended s 304 QCC.

190 Criminal Law Amendment Act 2017 (Qld).

191 Criminal Reform Amendment Act (No 2) 2006 (NT).

192 Crimes Amendment Ordinance (No 2) 1990 (ACT). 
Qld, ${ }^{193}$ South Australia, ${ }^{194}$ the ACT ${ }^{195}$ and the NT ${ }^{196}$ life imprisonment is still a mandatory penalty for murder, whereas elsewhere in the country it is now a maximum penalty. ${ }^{197}$ In the absence of abolition of the mandatory life imprisonment penalty for murder, reform bodies have argued for the retention and modernisation of the defence of provocation, rather than its abolition. ${ }^{198}$ No Australian jurisdiction has taken the same path in its approach to reform. ${ }^{199}$ However, similar to England and Wales, for all Australian jurisdictions, the decision to abolish or reform the defence was informed by two central concerns. 200 First, a growing concern that too often the provocation defence was used to justify male proprietorial anger towards a female partner 201 and/or a killer's response, grounded in homophobic masculinity, to a homosexual advance. ${ }^{202}$ Second, a concern that battered spouses, usually women who kill their abuser, fearing further serious abuse or death, should not be convicted of murder. ${ }^{203}$ While legislative reforms to self-defence have been introduced in WA204 and Victoria205 to respond to these issues, there are some homicide defendants in this category whose response may be found disproportionate to the risk of future harm. ${ }^{206}$ Both Victoria and Qld attempted to deal with this issue through the introduction of the ill-fated offence of 'defensive

193 Criminal Code Act 1899 (Qld), s 305.

194 Criminal Law Consolidation Act 1935 (SA), s 11.

195 Crimes Act 1900 (ACT) s 12.

196 Criminal Code Act 1983 (NT) s 157.

197 Crimes Act 1900 (NSW), s 19A; Crimes Act 1958 (Vic), s 3; Criminal Code Act 1924 (Tas), s 158. Note in WA life is now a 'presumptive' penalty for murder: see Criminal Code Compilation Act 1913 (WA), s 279(4).

198 Queensland Law Reform Commission, A Review of the Excuse of Accident and the Defence of Provocation Report (Report No 64, 2008) 57-63 (QLRC Report) 471; and re NT, see Andrew Hemming, 'Provocation: a totally flawed defence that has no place in Australian criminal law irrespective of sentencing regime' 14 University of Western Sydney Law Review 1-44, 3.

199 Crofts and Tyson (n 167 above).

200 Ibid.

201 Morgan (n 171 above).

202 Kent Blore, 'The homosexual advance defence and the campaign to abolish it in Queensland: the activist's dilemma and the politician's paradox' (2012) 12(2) Queensland University of Technology Law Journal 36-65. See also $R v$ Meerdink [2010] QCA 273; Green $v$ R [1997] HCA 50, (1997) 191 CLR 334.

203 Crofts and Tyson (n 167 above) 873.

204 Criminal Law Amendment (Homicide) Act 2008 (WA).

205 Crimes (Homicide) Act 2005 (Vic), s 9AC.

206 Osland $v$ R [1998] HCA 75; 197 CLR 316. 
homicide' in Victoria207 and in Qld the still operating 'defence of self-preservation'.208 Given the complexity of the responses across Australia, we focus on the most recent reforms to provocation in the Australian jurisdictions of Qld and NSW. These two states have decided to retain and reform the provocation defence in the past 10 years.

\section{Developments in Qld, Australia}

\section{Background to the reforms}

In 2005 the defence of provocation in s 304 of the Criminal Code 1899 (Qld) (QCC) stated:

When a person who unlawfully kills another under circumstances which, but for the provisions of this section, would constitute murder, does the act which causes death in the heat of passion caused by sudden provocation, and before there is time for the person's passion to cool, the person is guilty of manslaughter only.

A succession of cases had developed the interpretation of the provision. Essentially, it had three key elements: the defendant must kill 'in the heat of passion', where the passion was caused by sudden provocation and before there had been time for the passion to cool. Once raised on the evidence, it was for the prosecution to disprove it beyond reasonable doubt. ${ }^{209}$ Over time, the interpretation of the provision had become increasingly complex. Virtually any conduct could qualify as provocation unless the prosecution satisfied the jury beyond reasonable doubt that the 'hypothetical ordinary person' could not have reacted to the conduct in the way (that is the nature and extent of the reaction, rather than the precise physical form) in which the defendant acted. 210 While generally words alone, for example a confession of adultery, would not be considered sufficient provocation, case law had identified that in 'extreme or exceptional' circumstances words might be sufficient and it was 'the combination of circumstances' that needed to be evaluated. ${ }^{211}$ In a case emanating from Qld, the High Court of

207 Defensive homicide was introduced in 2008 (Crimes Act 1958 (Vic), s 9AD) and abolished six years later in 2014 (Crimes Amendment (Abolition of Defensive Homicide) Act 2014 (Vic), s 3(3)). See also Madeleine Ulbrick, Asher Flynn and Danielle Tyson, 'The abolition of defensive homicide: a step towards populist punitivism at the expense of mentally impaired offenders' (2016) 40 Melbourne University Law Review 324; Kate Fitz-Gibbon and Sharon Pickering, 'Homicide law reform in Victoria, Australia: from provocation to defensive homicide and beyond' (2012) 52(1) British Journal of Criminology 159.

208 Criminal Code Act 1899 (Qld), s 304B.

209 Pollock $v$ The Queen [2010] HCA 35 [6]-[7].

210 Ibid [67].

211 Buttigieg $v$ The Queen (1993) 69 A Crim R 21, 37. 
Australia had clarified that the requirement for 'sudden provocation' did not mean that the accused's response to the provocation must be 'immediate', but rather the killing must occur when the person is in a state of loss of self-control caused by the provocative conduct. 212

Towards the end of 2005, 28-year-old Damian Sebo was charged with the murder of his 16-year-old girlfriend, Taryn Hunt. They had been in a sexual relationship for around two years. Sebo killed her as they were returning from the casino. The defence case was that Hunt had taunted Sebo about her relationships with other men. The defence asserted that, when Hunt said she planned to continue to cheat on him, Sebo struck her several times with a steering wheel lock. Sebo took Hunt to hospital, but she died two days later from her injuries. Initially charged with murder, Sebo offered to plead guilty based on Hunt's 'provocative' taunts and the Crown accepted the plea. Sebo was sentenced to 10 years' imprisonment. The Attorney General appealed the sentence on the basis that this was inadequate, but the appeal was dismissed. ${ }^{213}$ There was significant community disquiet about the conviction and sentence. ${ }^{214}$ In response, the Attorney General asked the Queensland Law Reform Commission (QLRC) to review the defence of provocation. 215

\section{Law Reform in Qld}

The Attorney General's reference stated that the QLRC should have regard to 'the existence of a mandatory life sentence for murder and the Government's intention not to change the law in this regard'.216 At the same time, the Attorney General asked the QLRC to consider 'whether the partial defence of provocation (section 304 of the Criminal Code) should be abolished, or recast to reflect community expectations'.217

In making its recommendations, the QLRC was influenced by data showing that in Qld 29 per cent of all homicides were intimate partner homicides and 80 per cent of the intimate partner homicides involved

212 Pollock $v$ The Queen [2010] HCA 35 [54]; Elizabeth Sheehy, Julie Stubbs and Julia Tolmie, 'Defences to homicide for battered women: a comparative analysis of laws in Australia, Canada and New Zealand' (2012) 34 Sydney Law Review 467-492, 481.

$213 R v$ Sebo, ex parte Attorney General [2007] QCA 426. For further consideration of the case, see QLRC Report (n 198 above).

214 Mark Oberhardt, 'Damian Sebo's jail term not increased for Taryn Hunt's death' Courier Mail (Brisbane, 29 November 2007).

215 QLRC Report (n 198 above), see terms of reference, app 1, 521-522

216 Ibid 621.

217 Ibid 621, (c). 
men killing women. ${ }^{218}$ Further, the QLRC quoted statistics that 14 per cent of killings were motivated by the end of a relationship and 58 per cent arose from a domestic argument. ${ }^{219}$ The QLRC identified that those who have size and strength are generally the ones who respond to provocation with violent rage because they have the power to do so. ${ }^{220}$ Furthermore, the QLRC identified a number of cases where the provocation consisted of words including taunts, insults and admissions of infidelity from the victim ${ }^{221}$ and found that in provocation cases 'the reduction to manslaughter is artificial because it masks the fact that the killing under provocation was an intentional one'. ${ }^{222}$ However, 'constrained'223 by the mandatory life imprisonment sentence in Qld, the QLRC rejected the abolition argument primarily 'because [of] the need to preserve the defence for those who genuinely deserve relief from mandatory life imprisonment, for example, the battered woman who loses control after discovering that her abuser has been raping their infant child'.224

In recasting the provocation defence, the QLRC had several goals. It sought to recognise that, in extreme situations, human frailty could cause a person to react with lethal violence, and compassion in sentencing was deserved. ${ }^{225}$ The QLRC sought to limit the application of the defence to retaliations to serious wrongs, hence it recommended an overarching requirement that the defence should not be available in response to provocation that involves words alone, or mainly words unless the circumstances were 'extreme or exceptional'.226 Further, it sought to ensure that the defence did not operate in a gender-biased way and recommended that, unless circumstances were extreme or exceptional, the deceased's choice about the relationship could

218 Megan Davies and Jenny Mouzos, Homicide in Australia: 2005-06 National Homicide Monitoring Program Annual Report (Australian Institute of Criminology 2006) 23; QLRC Report (n 198 above) 226.

219 Davies and Mouzos (n 218 above); QLRC Report (n 198 above) 227.

220 QLRC Report (n 198 above) 465.

221 Ibid 467; $R v$ Auberson [1996] QCA 321, $R v$ Smith [2000] QCA 169, $R v$ Perry Indictment No 312 of 2003, $R v$ Schubring, ex parte $A-G$ (Qld) [2005] 1 Qd R 515, $R v$ Sebo [2007] QCA 426.

222 QLRC Report (n 198 above) 469

223 Ibid 474.

224 Ibid 471, indirectly referencing similar facts in the case of $R v R$ (1981) 28 SASR 321.

225 Ibid 21.1, 500.

226 Ibid rec 21.2, 500 . 
not amount to provocation. ${ }^{227}$ Finally, under a new formulation of provocation the QLRC found that the defendant should be required to prove, on the balance of probabilities, that 'confronted with provocation, he or she retaliated in a state of intense emotion and failed to exercise self-restraint'.228 The QLRC also recommended the reversal of the onus of proof in circumstances where provocation is raised. In considering the onus of proof in its Report, the QLRC noted the conflict between two principles: first, 'the great principle of the common law that the onus of proof of a criminal charge should rest on the prosecution'; second, 'a general principle that a party seeking to take advantage of a particular rule (in this case one allowing murder to be mitigated to manslaughter because of provocation) should carry the onus of persuasion in relation to the rule'. ${ }^{229}$ The QLRC identified several other examples of reversal of the onus with respect to defences in the QCC 230 and determined that, among other things, the defendant is in the best place to articulate the claim, the reversed onus would result in claims that are more well-articulated and the trial judge will have enhanced capacity to prevent unmeritorious claims. ${ }^{231}$

Parliament largely followed the recommendations of the QLRC and introduced changes to the provocation defence in 2011.232 The previous language of the defence is retained in the first paragraph of the reformed provision: the fatal act must be done in the 'heat of passion', in response to 'sudden provocation' and 'before there is time for the person's passion to cool'. ${ }^{233}$ However, several limiting subsections are now included, reflecting the recommendations of the QLRC Report.

227 Ibid rec 21.3, 500. Note in this context, the QLRC Report recommended further consideration of the development of a separate defence for battered persons who kill: ibid rec 21.4, 501. Subsequent to the QLRC enquiry, a report was prepared on the possibility of introducing a new defence specifically targeting battered persons; Geraldine Mackenzie and Eric Colvin, Homicide in Abusive Relationships: A Report on Defences (Bond University 2009) prepared for the Attorney General and Minister for Industrial Relations. The findings of this report underpinned the introduction of new partial defence, s 304B of the Criminal Code (Qld): 'Killing for preservation in an abusive domestic relationship'. For discussion of the operation of this defence. See Heather Douglas, 'A consideration of the merits of specialised homicide offences and defences for battered women' (2012) 45(3) Australian and New Zealand Journal of Criminology 367.

228 QLRC Report (n 198 above) 497 rec 21.5.

229 Ibid 196.

230 For example, diminished responsibility (s 304A QCC), mistake of fact regarding age in a number of sexual offences against minors (ss 209, 211, 215 QCC).

231 QLRC Report (n 198 above) 492-493.

232 Criminal Code and Other Legislation Amendment Act 2011 (Qld).

233 Provocation remains undefined in the legislation and takes its meaning from the common law: $R v$ Buttigieg (1993) 69 A Crim R 21; Stingel $v$ The Queen (1990) 171 CLR 312, 326. Note also loss of self-control may arise from anger or resentment, or other emotions such as fear or panic: Van Den Hoek $v$ The Queen (1986) 161 CLR 158. 
The reformed provision identifies that words alone cannot constitute provocation 'except in circumstances of an exceptional character' (section 304(2) QCC). Further, except in 'circumstances of an exceptional character' the provocation defence does not apply, in the context of a domestic relationship, ${ }^{234}$ where:

(c) the sudden provocation is based on anything done by the deceased, or anything the person believes the deceased has done-

i) to end the relationship; or

ii) change the nature of the relationship; or

iii)to indicate in any way that the relationship may, should or will end, or that there may, should or will be a change to the nature of the relationship. (section 304(3) QCC)

The provision states that, when determining whether the character of the provocation is exceptional, regard may be had to any relevant history of violence (section 304(7) QCC). Importantly, this sub-section explicitly allows the court to take account of a history of violence, both in cases where a domestic violence abuser ultimately kills his victim and in cases where the victim kills her abuser. Evidence of the history of abuse provides context to the fatal conduct. The objectives of the reforms were to 'recast the defence of provocation ... to address its bias and flaws'.235 The Explanatory Notes for the reformed provocation provision highlighted the concern with the historical gender bias of the defence:

... it is not uncommon for men who kill their intimate partners to raise the defence of provocation on the basis that they were provoked to kill by their partner's infidelity, insults or threats to leave the relationship ... The amendments will: remove insults and statements about relationships from the scope of the defence; recognise a person's right to assert their personal or sexual autonomy; and will reduce the scope of the defence being available to those who kill out of sexual possessiveness or jealousy. 236

The onus is on the defence to prove that $\mathrm{s} /$ he is guilty of manslaughter by provocation (section 304(9) QCC) to the balance of probabilities standard. The onus is on the defendant to prove more probably than not that there was provocation by the deceased, that the defendant lost control in response to the provocation and the defendant was still provoked when doing the act that caused the victim's death. ${ }^{237}$ There

234 Defined under s 13 of the Domestic and Family Violence Protection Act 2012 (Qld). See s 304(5): 'For subsection (3)(a) despite the Domestic and Family Violence Protection Act 2012, section 18(6), a domestic relationship includes a relationship in which 2 persons date or dated each other on a number of occasions.'

235 Criminal Code and Other Legislation Amendment Bill 2010, Explanatory Notes, 1.

236 Ibid 2-3.

237 Supreme and District Courts Criminal Directions Benchbook [98]. 
has been almost no debate about this change. Indeed, subsequent enquiries into reform of homicide defences in other Australian states have merely noted this change without significant comment. ${ }^{238}$ This apparent acceptance can be contrasted with the United Kingdom where the onus of proof remaining with the prosecution has been considered a matter of human rights protection and is strongly guarded.239

After the QLRC Report was handed down, barrister John Jerrard was tasked to head a Special Committee to consider the so-called 'homosexual advance defence'.240 The Special Committee determined that claims of a homosexual advance as a provocation to murder were not common but had played a role in two cases. ${ }^{241}$ The special committee was divided about the necessity for reform but ultimately recommended change. In 2017, legislative reforms introduced a further limitation on the application of the provocation defence. 242 Sudden unwanted sexual advances, 243 except when of an exceptional character, are no longer recognised as provocation under the Qld provocation defence (section 304(4) QCC).

\section{Implementing the Qld reforms}

The legislative effort to exclude the provocation defence in the context of sexual infidelity and circumstances where women appear to have changed or left the relationship have been considered in two recent, and very similar, cases: $R v$ Peniamina ${ }^{244}$ and $R v$ Pilcher. ${ }^{245}$ The two

238 See, for example, South Australian Law Reform Institute, The Provoking Operation of Provocation: Stage 2 (South Australian Law Reform Institute 2018) 21.

239 See, for example, Keogh $v R$ [2007] EWCA Crim 528.

240 John Jerrard, Special Committee Report on Non-Violent Sexual Advances (Special Committee Report to the Queensland Attorney-General, Parliament of Queensland 2012). See also David Mack, “But words can never hurt me": untangling and reforming Queensland homosexual advance defence' (2013) 35 Sydney Law Review 167.

$241 R v$ Peterson and Smith (Unreported, Maryborough Circuit Court, 14 October 2011); $R$ v Meerdink and Pearce (Unreported, Maryborough Circuit Court, 13 May 2010).

242 Criminal Law Amendment Act 2016 (Qld) Clause 10.

243 Under s 304(4) QCC 'unwanted sexual advance' to a person, means a sexual advance that-(a) is unwanted by the person; and (b) if the sexual advance involves touching the person-involves only minor touching. Example-patting, pinching, grabbing or brushing against the person, even if the touching is an offence against s 352(1)(a) or another provision of this Code or another Act' (see s 304(11) QCC).

244 [2019] QCA 273.

245 [2020] QCA 8. A model direction is included in the Supreme and District Courts Bench Book, Queensland Courts (n 237 above) [98]. 
cases highlight the unpredictable ways in which law reforms designed to address gender inequity are sometimes implemented and the difficulty of law reform. 246

In $R v$ Peniamina,247 Arona Peniamina killed his wife Sandra Peniamina. In the months leading up to the homicide, Arona and Sandra had been having marriage problems. She had been sleeping in the spare room and Arona believed she was having an affair with a man in New Zealand. Arona told family members he was worried about her taking the children overseas. On the night Arona killed Sandra, he had tried to talk to her about text messages he found on her mobile phone; he presumed they were from her boyfriend. Arona told police he thought she did not care, that he hit her and her mouth began to bleed. She moved into another room and obtained a knife 'presumably to defend herself against further attack'.248 Arona grabbed the knife by the blade to try to take it off her, she pulled the knife back and Arona's hand was cut in the process. Arona told the police 'I feel my hand really pain ... just more angry and more angry ... I can't stop that time.'249 Sandra tried to run away, and Arona stabbed her over twenty times with the knife, killing her. 250 The jury convicted him of murder. He appealed against the conviction based on errors with respect to jury directions on the provocation defence, especially with respect to section 304(3) QCC.

Both at trial and on appeal, the defence argued it was the brandishing of the knife, which led Arona to grab the blade and his hand to be cut, that was the 'sudden provocation' that caused him to lose self-control and 'tipped [him] over into a rage', 251 rather than something Sandra did to change the nature of the relationship. ${ }^{252}$ The Crown case was that the provocation was the acts done by Sandra Peniamina 'to change the nature of the relationship', and this put the defence in the position where they needed to prove that the provocative acts were of 'an extreme and exceptional character' in order to successfully engage the provocation defence. ${ }^{253}$ The trial judge had directed the jury that the defence had to prove provocation was not based on something Sandra

246 And, indeed, the difficulties of changing law through legislation: see Kate FitzGibbon, 'Replacing provocation in England and Wales: examining the partial defence of loss of control' (2013) 40(2) Journal of Law and Society 280, 281, especially fn 2 for a list of references.

247 [2019] QCA 273.

$248 R v$ Peniamina [2019] QCA 273 [94] (Applegarth J).

249 Peniamina $v R$ B32/2020, appellants' submissions to the High Court of Australia, 3.

$250 R v$ Peniamina [2019] QCA 273 [97] (Applegarth J).

251 Ibid [118].

252 Ibid [69], [99].

253 Ibid [67]. 
did to change the nature of the relationship. Arona appealed and in a 2:1 majority, the appeal was dismissed.254

Applegarth J, in the majority on appeal, said that section 304(3) QCC would be engaged where 'the sudden provocation was closely related to a thing done by the deceased to change the relationship'. ${ }^{255}$ He noted that the defendant might nominate a more immediate act of provocative conduct (eg in this case the grabbing of the knife), but the evidence might show that the sudden provocation 'was based on a thing done by the deceased to change the relationship'.256

The factual question of whether the claimed (or assumed) sudden provocation was 'based on' an act of the deceased done to change the relationship calls for an evaluation of the chain of events and the causative potency of the act of the deceased. The statute uses words which suggest that the act of the deceased must have been a foundation of what followed. A mere connection between the act and the sudden provocation, in that the act made some contribution in terms of cause and effect to the eventual outcome is unlikely to be sufficient to support a finding that the sudden provocation was 'based on' the act.257

Applegarth $J$ found that the words 'based on' have an ordinary meaning connoting a 'substantial' causal connection. ${ }^{258} \mathrm{He}$ found there might be a sufficient connection where, even though something had occurred between the deceased's acts in ending the relationship and the accused's loss of self-control, 'the intervening matter is a likely or not unexpected consequence of a thing done to end or change a relationship'.259

Applegarth $\mathrm{J}$ expressed concern that if interpreted too narrowly section 304(3) QCC would be deprived of its intended operation:

In my view, it would be an odd, and seemingly unintended, result if a defendant could effectively avoid the practical operation of s 304(3) by nominating the most immediate act of the deceased (eg a blow struck in self-defence during a fight that quickly followed her act in trying the leave the relationship) as the provocative act. 260

Morrison JA also dismissed the appeal. He found that the phrase 'based on' requires the change of relationship to be a 'foundation' or 'basis' for the sudden provocation. ${ }^{261}$ Morrison JA also emphasised

254 Applegarth $\mathrm{J}$ and Morrison JA dismissed the appeal; McMurdo J allowed the appeal and would have ordered a retrial.

255 R v Peniamina [2019] QCA 273 [182].

256 Ibid [182].

257 Ibid [184].

258 Ibid [185].

259 Ibid [166].

260 Ibid [169].

261 Ibid [16]. 
that 'belief' of the accused that the victim had acted to end or change the relationship, or had indicated that she would end of change it, was required. It was not necessary under section 304(3)Q CC on Morrison JA's view for the victim to have actually done anything to end or change the relationship. 262

However, McMurdo JA, dissenting, would have allowed the appeal. Interpreting the application of section 304(3) QCC narrowly, ${ }^{263}$ he found that, in order for section 304(3)QCC to be engaged, the jury had to find that what was done by the deceased with the knife was done to end or change the nature of the relationship. In making this finding, he preferred an interpretation of the circumstances that excised two discrete actions, the victim's action with the knife and the accused's response, from their relationship context and history.

On appeal to the High Court, the majority (Bell, Gageler and Gordon JJ) preferred McMurdo JA's conclusion in $R v$ Peniamina that the words 'based on' 'signify a relation of causation simpliciter between the sudden provocation and the thing done by the deceased to change the relationship', finding that Applegarth J's 'wide construction' gives the words 'based on' an 'uncertain operation'.264 The majority found that the defence requires the accused 'to nominate the thing done (or believed to have been done) by the deceased that induced his or her loss of self-control' and to prove not only that the killing was done in a state of loss of self-control but that the state was induced by the nominated conduct. 265 The appeal was allowed and a new trial ordered. The minority (Keane and Edelman JJ) found that the phrase 'based on' is broader than the phrase 'caused by', and the deliberate choice of this different language would be impermissible for the courts to ignore. 266 The minority suggested that it was 'unlikely' that Parliament could be taken to have intended that the operation of section 304(3) QCC would be 'a matter for the forensic choice of an accused, superintended by the judge, and removed from consideration by a jury' and said that 'the knife incident cannot be viewed in isolation from the other conduct of the deceased leading up to the killing, or the beliefs of the appellant in relation to that conduct'.267 They would have dismissed the appeal.

$R v$ Pilcher [2020] QCA 8 was decided three months after $R v$ Peniamina [2019] QCA 273. Dane Pilcher ${ }^{268}$ had been in a sexual relationship with the deceased, Corinne Henderson, for two years.

262 Ibid [20], [21].

263 Ibid.

264 Peniamina $v R$ [2020] HCA 47, [12], [16].

265 Ibid [26].

266 Ibid [87], [88].

267 Ibid [103]; [105].

$268 R v$ Pilcher [2020] QCA 8. 
They had separated at the deceased's instigation around three months prior to the homicide. Henderson had begun a new relationship. It was common ground that Pilcher killed Henderson in her house, stabbing her with a kitchen knife. On the day Pilcher killed her, a friend of Pilcher's had forwarded Facebook photos of the victim with her new partner to Pilcher. Pilcher had become 'distressed, upset and emotional'. ${ }^{269}$ He went out drinking and later that day made his way to the victim's house. At this point, the prosecution case relied primarily on the testimony of the killer.270 When Pilcher arrived at the house, he knocked but no one answered, so he broke the kitchen window and climbed in. He confronted the victim in the kitchen, she asked him to leave six times, and, on Pilcher's account, she stabbed him with a knife and, in the context of trying to get the knife from her, he killed her, stabbing her 21 times. The main defence relied on by the accused was accident - or if intent was found, self-defence. Ultimately, the jury was directed to consider self-defence, accident, compulsion and provocation at trial. At trial, the defence had not explicitly run the defence of provocation, however, it was raised on the evidence. The defence team proceeded on the basis that section 304(3) QCC applied to the circumstances, namely that the basis of the provocation was Henderson's decision to separate from Pilcher. As a result, the trial judge's direction to the jury was that the provocation defence pursuant to section 304(1) QCC was not applicable unless the jury were satisfied that the sudden provocation had occurred in circumstances of a 'most extreme and exceptional character'271 pursuant to section 304(3) QCC. Pilcher was convicted of murder. He appealed against the conviction, in part on the basis that the jury was misdirected on provocation.

This time the Court of Appeal was required to follow the precedent of $R v$ Peniamina, and much of Applegarth J's interpretation of section 304(3) QCC in that case is repeated by McMurdo JA272 in his judgment in $R v$ Pilcher. Recall McMurdo JA had earlier dissented in $R v$ Peniamina. ${ }^{273}$ However McMurdo JA (Fraser JA concurring) ${ }^{274}$ allowed the appeal, this time because the jury was not instructed to first consider the question of whether the evidence engaged section 304(3) QCC. McMurdo JA found that the trial judge had missed an important step in his directions to the jury. The trial judge had assumed

269 Ibid [13].

270 The only other person present was the victim who, of course, cannot testify; Jenny Morgan, 'Provocation law and facts: dead women tell no tales, tales are told about them' (1997) 21 Melbourne University Law Review 237-276.

271 R v Pilcher [2020] QCA 8 [4].

272 Ibid [34]-[36].

273 R $v$ Peniamina [2019] QCA 273.

$274 R v$ Pilcher [2020] QCA 8 [1]. 
that section 304(3)QCC was engaged and directed the jury that they would need to identify exceptional circumstances to find provocation and convict on manslaughter. Crow J, in the minority, would not have allowed the appeal on this basis. He found that the question of whether section 304(3)QCC was relevant was not in issue between the parties, so the trial judge's direction was appropriate. 275

These two Qld cases where men killed their (ex)partners in the shadow of separation provided an opportunity to test the application of the reformed provocation defence in Qld. Applegarth J's judgment in $R v$ Peniamina ${ }^{276}$ viewed the alleged provocation within the broader history of the relationship between the killer and victim, finding that the killer's loss of control was 'based on' his partner's decision to change the relationship. In contrast, McMurdo JA (and subsequently the majority of the High Court) takes a narrower approach, extracting a discrete incident of provocation from its broader context. In determining the application of section 304(3) QCC McMurdo JA refuses to take into account the history of the relationship between the killer and victim in locating loss of self-control. McMurdo JA's judgment in $R v$ Peniamina considers loss of self-control arises from a single incident, ignoring the surrounding circumstances, including the killer's building frustration that their partner has chosen to leave. This approach of refusing to see the provocative act in its broader context would allow what Fitz-Gibbon has described as 'jealous man provocation' to continue to be applied. ${ }^{277}$

In the context of this article, it is of interest to consider how the narrow versus broad approach might apply to a woman whose 'loss of control' develops from an experience of long-term coercive control and family violence who finally 'snaps' when confronted with her partner's sexual infidelity (eg the circumstances facing Sally Challen in England). 278 On McMurdo JA's narrow approach the abusive partner's sexual infidelity would not be seen in its broader context and section 304(3) QCC would apply. This would mean the killer has an extra hurdle: unless the sexual infidelity could be found to have occurred 'in circumstances of an exceptional character', the provocation defence pursuant to section 304(1) QCC would not be available to her. Applying Applegarth J's broader approach, the history of coercive control would be part of the context: that is the loss of control would potentially be 'based on' coercive control and the extra hurdle of

275 Ibid [95].

$276 R v$ Peniamina [2019] QCA 273.

277 Kate Fitz-Gibbon, 'Homicide law reform in New South Wales: examining the merits of the partial defence of "extreme" provocation' (2017) 40 Melbourne University Law Review 769, 788. See also Tyson (n 169 above); Jeremy Horder, Provocation and Responsibility (Clarendon Press 1992) 192-193; Morgan (n 171 above); also see Howe (n 171 above) 130.

$278 R v$ Challen [2011] EWCA Crim 2019. 
section 304(3) avoided. Of course, in either case, if section 304(1) QCC would ultimately apply, the killer would need to satisfy the jury to the balance of probabilities standard that she was responding in the 'heat of passion' to 'sudden provocation' 'before there was time for her passion to cool'. As observed by the High Court:

The law [in Australia] requires that the killing occur while the accused is in a state of loss of self-control that is caused by the provocative conduct, but this does not necessitate that provocation is excluded in the event that there is any interval between the provocative conduct and the accused's emotional response to it and if the killing is determined to be 'premeditated' (ie not done in the heat of passion while self-control was lost) the jury would be required to convict of murder. ${ }^{279}$

One of the difficulties of the Challen case was that Sally Challen went to the victim's house armed with a hammer. Nevertheless, if the Qld provocation law had applied to Sally Challen, under the broad approach, it is possible the jury would have been directed to consider provocation. Applying the broad approach, a person in Challen's circumstances may have been able to convince a jury on the balance of probabilities that the provocation was the coercive control that she experienced over a long period from the victim and that she was still responding to that provocation when she killed. Under the narrow approach, which, subsequent to the High Court's decision in Peniamina $v R$, is how the provision must be interpreted in Qld, she would have an extra hurdle to convince the jury that the sexual infidelity was of an 'exceptional character'.280

\section{Developments in NSW, Australia}

\section{Background to the reforms}

NSW introduced significant reforms to the defence of provocation in 1982,281 in part to broaden its application to battered women who killed their intimate partner. 282 Under those reforms the mandatory

279 Pollock $v$ The Queen [2010] HCA 35 (20 October 2010) [54] (French CJ, Hayne, Crennan, Kiefel and Bell JJ) allowing for a 'slow burning' loss of control: $R v$ Chhay (1994) 72 A Crim R 1, 13. Although see Andrew Hemming, 'Impermissibly importing the common law into criminal codes: Pollock $v$ The Queen' (2011) 18 James Cook University Law Review 113, for criticism of this case.

280 Note s 304(7) QCC allows the history of family violence to be taken into account where the alleged provocation is based on the deceased's decision to leave or change the relationship. As observed earlier, the High Court of Australia is set to rule on the correctness of the broad versus narrow approach: Peniamina $v$ The Queen [2020] HCA Trans 75 (5 June 2020).

281 For an overview of the history and approach to reform in NSW, see Fitz-Gibbon (n 135 above) ch 7, 150-177.

282 Report of New South Wales Task Force on Domestic Violence to Honourable N K Wran QC, MP Premier of New South Wales, July 1981 (Government Printer 1981). 
life imprisonment penalty was abolished (and reformed to maximum life). In 2009 section 23(1) Crimes Act 1900 (NSW) provided:

Where, on the trial of a person for murder, it appears that the act or omission causing death was an act done or omitted under provocation and, but for this subsection and the provocation, the jury would have found the accused guilty of murder, the jury shall acquit the accused of murder and find the accused guilty of manslaughter.

Under the provision, provocation could be established where:

... an act or omission was the result of a loss of self-control by the defendant that was induced by any conduct of the deceased 283 toward or affecting the defendant; and the conduct of the deceased was such that it could have induced an ordinary person to have so far lost self-control as to have formed intent to kill or inflict grievous bodily harm. ${ }^{284}$

In 2009, Chamanjot Singh was charged with the murder of his wife, Manpreet Kaur, after he cut her throat several times with a boxcutter.285 Singh pleaded guilty to manslaughter but not guilty to murder, claiming that his wife had provoked him by threatening to deport him, and by her suggestions that she had never loved him and was in love with someone else. ${ }^{286}$ The jury verdict was manslaughter. ${ }^{287}$ The sentencing judge observed that the jury were not convinced that an ordinary person in Mr Singh's position would not have responded to the alleged provocative conduct in the manner that he did288 and sentenced Singh to eight years with a non-parole period of six years. The case sparked significant debate in the community and calls for a review of the defence. 289

\section{Law reform in NSW}

A month after Singh was sentenced the legislative council of the NSW Government established a Select Committee on the Partial Defence of Provocation (the Committee). The terms of reference included that the Committee should report on abolishing or amending the provocation

283 The conduct could include 'grossly insulting words or gestures', see s 23(2)(b) (repealed).

284 Summary extracted from Select Committee on the Partial Defence of provocation, The Partial Defence of Provocation: Final Report (NSW Legislative Council 2013) 13. See s 23(2)(a) Crimes Act 1900 NSW (repealed).

285 Singh $v R$ [2012] NSWSC 637 [30].

286 Ibid [1], [27].

287 Ibid [1]-[2].

288 Ibid [2].

289 Paul Bibby and Josephine Tovey, 'Six years for killing sparks call for law review' Sydney Morning Herald (Sydney, June 2011). 
defence. ${ }^{290}$ The Committee chairman's foreword referred to the Singh case stating: 291

It is unacceptable that the law offers a partial defence to people who kill in response to 'provocative' circumstances which are, in fact, a normal part of human experience, such as being told a relationship is going to end, discovering infidelity, or feeling jealous or betrayed. ${ }^{292}$

However, the Committee was unable to agree that the provocation defence should be abolished, primarily because it accepted that, for many women who are long-term victims of abuse, the provocation defence may be appropriate. The Committee settled on recommending substantial reforms to the defence, ${ }^{293}$ and, drawing in part on the model developed by the English Law Commission discussed earlier in this article, ${ }^{294}$ recommended a 'gross provocation' model, 295 available only where the defendant acted in response to words or conduct which caused him or her to have a justifiable sense of being seriously wronged. 296

Following the release of the Committee's report, the Crimes Amendment (Provocation) Bill 2014 was introduced. Parliament made more limited changes to the defence than the Select Committee recommended. 297 The reformed provocation defence in NSW provides for a verdict of manslaughter in cases where the killer lost control in response to 'extreme provocation,' defined as a 'serious indictable offence'.298 A non-violent sexual advance or conduct incited by the accused to provide an excuse to use violence against the deceased are expressly excluded as forms of extreme provocation. ${ }^{299}$

290 NSW Legislative Council, Inquiry into the Partial Defence of Provocation: Terms of Reference (2012).

291 Select Committee on the Partial Defence of Provocation, The Partial Defence of Provocation: Final Report (NSW Legislative Council 2013).

292 Ibid $x$.

293 Ibid $x$.

294 Law Commission (53 above).

295 Select Committee (n 291 above) 191.

296 Crofts and Tyson (n 167 above) 876.

297 Thomas Crofts and Arlie Loughnan, 'Provocation, NSW style: reform of the defence of provocation in NSW' [2014] Criminal Law Review 109. Note also that some submissions recommended there should be clear limits on the defence, for example provocation should not include things done or said to change the relationship. See eg Thomas Crofts and Arlie Loughnan, 'Provocation: the good, the bad and the ugly' (2013) 37 Criminal Law Journal 23, 36 .

298 Crimes Act 1900 (NSW), s 23(1) and (2).

299 Ibid s 23(3). Provocation is a mitigating factor for the purposes of sentencing: $s$ 21A(3)(c) Crimes (Sentencing Procedure) Act 1999 (NSW). 
When introducing the legislation, the Attorney General discussed the threshold requirement that the provocation would have to be a 'serious indictable offence'. $300 \mathrm{He}$ observed that victims of domestic violence will be able to rely upon the partial defence in appropriate cases:

Domestic violence, particularly long-term abuse, will generally involve conduct involving serious indictable offences, such as the range of assaults in the Crimes Act 1900. Even where abuse is not physical, but psychological, it may amount to the serious indictable offence of stalking or intimidation set out in section 13 of the Crimes (Domestic and Personal Violence) Act 2007.301

While the reforms were said to allow for the possibility that a woman who killed her abuser in response to domestic violence might successfully plead the defence of provocation, it is likely that many abused women would be excluded from claiming it. Non-physical forms and patterns of domestic abuse, including coercive control, are increasingly recognised as entrapping women in abusive relationships. ${ }^{302}$ However, unlike England and Wales, there is currently no offence of coercive control in NSW. ${ }^{303}$ Unless an abused woman can prove that the abuse she experienced was a 'serious indictable offence', the abuse will not reach the threshold of provocation. Even though there is no requirement under NSW law that the provocation occur immediately before the fatal act,304 allowing for a slow-burning provocation, 'on-going emotional abuse, such as belittling, persistent taunts and criticism' would not meet the threshold of a 'extreme provocation' required for provocation. 305

To date there have been no cases under the 2014 reformed provocation provision dealing with abused women who kill their abuser. There are, however, four reported cases that have considered the interpretation of 'extreme provocation'. Three of the cases have considered when the provocative act reaches the threshold of 'serious indictable offence'. A fourth case is interesting for its facts and the role of relationship choice by the wife of the accused in provocation to kill.

300 Crimes Amendment (Provocation) Bill 2014, second reading speech, Reverend the Hon Fred Nile, NSW Legislative Council, Hansard and Papers, Wednesday 5 March 2014, p 27033.

301 Ibid.

302 See, for example, Evan Stark, 'The "coercive control framework": making law work for women' in Marilyn McMahon and Paul McGorrery, Criminalizing Coercive Control (Springer 2020) 33-50.

303 Cf England and Wales: Serious Crime Act 2015, s 76.

304 Crimes Act 1900 (NSW), s 23(4).

305 Crofts and Loughnan, 'Provocation, NSW style' (n 297 above) 122. 


\section{Implementing the NSW reforms}

In $R \quad v$ Turnbull (No 5)306 the victim, a government-employed compliance and regulation officer, was inspecting the offender, Turnbull's, property on suspicion of illegal land-clearing when Turnbull killed him. Turnbull claimed he was stalked by the victim. The trial judge accepted that an offence of stalking or intimidation may be a 'serious indictable offence for the purpose of the provocation defence'.307 However, she refused, on the facts, to direct the jury to consider provocation as she was not satisfied the deceased's behaviour met the threshold for the offences of intimidation or stalking. ${ }^{308}$ The judge referred to the Attorney General's second-reading speech, noting that the requirement of 'serious violent offence' will 'ensure that members of the community who are lawfully going about their business do not inadvertently "provoke" another person to form an intention to kill or seriously injure them'.309 In this case, the victim was lawfully 'going about his business'. The victim 'may have been rude, abrupt, perhaps even overzealous in the performance of functions in the course of employment. The issue under consideration here is not one of best practice, but whether conduct may constitute a serious criminal offence.'310

How much evidence is required before the defence satisfies the evidential onus that the victim committed a 'serious violent offence', allowing the defence of provocation to be put before the jury, was considered in $R v$ Cliff (No 5). 311 Cliff fatally stabbed his neighbour 312 and was charged with murder. He alleged the victim had struck him from behind, causing breathing difficulty. There was medical evidence that Cliff had soft tissue injuries, although their cause was unclear. Cliff argued that the partial defence of provocation should be left to the jury. Campbell J concluded:

... there is some evidence, being more than a mere scintilla, that the conduct of [the victim], if the evidence of the accused is accepted, as at least being a reasonably possible version of events, amounted to the serious indictable offence of assault occasioning actual bodily harm. 313

306 [2016] NSWSC 439.

$307 R v$ Turnbull (No 5) [2016] NSWSC 439 [75].

308 Ibid [77]. Note the judge accepted the possibility that the defence might adduce evidence of a serious indictable offence during the trial that would be capable of raising the defence of provocation: see [118].

309 Ibid [60].

310 Ibid [77].

311 [2018] NSWSC 166.

312 There were 34 stab wounds: $R v$ Cliff (No 6) [2018] NSWSC 587 [11].

$313 R v$ Cliff (No 5) [2018] NSWSC 166 [18]. 
Notably, in considering his gatekeeping role with respect to the defence of provocation, Justice Campbell highlighted a statement from Lord Tucker in Bullard $v$ R:314

Every man on trial for murder has the right to have the issue of manslaughter left to the jury if there is any evidence upon which such a verdict can be given. To deprive him of this right must of necessity constitute a grave miscarriage of justice and it is idle to speculate what verdict the jury would have reached. 315

The judge determined that provocation should be left to the jury.

McDonald ${ }^{316}$ was charged with murder after he stabbed his brother once in the chest with a carving knife. McDonald lived next door to his brother and claimed that, in the weeks leading up to the fatal stabbing, his brother and his brother's wife had verbally abused him and treated him disrespectfully. On the night of the stabbing, McDonald heard the deceased having a noisy argument and a door was slammed. McDonald entered his brother's house in response to the noise and 'snapped' in a 'moment of madness' stabbing the victim. ${ }^{317} \mathrm{McD}$ onald claimed that his brother's behaviour amounted to provocation. 318 The trial judge considered there was sufficient evidence of 'threshold facts', 319 accepting that the victim's conduct was an indictable offence (intimidation). 320 In considering this, Harrison $J$ said that the legislative reference to serious indictable offence 'was undoubtedly formulated with a broad range of serious criminal conduct in mind', and the fact that 'the conduct of which Mr McDonald complains is possibly at the lower end of the spectrum is entirely beside the point. It is clearly capable of constituting a serious indictable offence.'321 Harrison $J$ pointed to evidence that the accused stated the conduct of the deceased had caused him to lose self-control, and there was no evidence to refute it. Finally, the judge determined the conduct of the deceased 'could' have caused an ordinary person to lose self-control to the extent of intending to kill or inflict grievous bodily harm on the deceased, and thus provocation should be left to the jury. ${ }^{322}$

314 [1957] AC 635, 644.

315 While provocation was left for the jury's consideration, ultimately the jury verdict was murder: $R v$ Cliff (No 6) [2018] NSWSC 587 [3].

$316 R v$ McDonald [2019] NSWSC 839.

317 Ibid [16].

318 Crimes Act 1900 (NSW), s 23(3)(2)(b).

$319 R v$ McDonald [2019] NSWSC 839 [40].

320 Contrary to s 13(1) of the Crimes (Domestic and Personal) Violence Act 2007.

$321 R v$ McDonald [2019] NSWSC 839 [38].

322 McDonald was convicted of manslaughter: ibid [45]. McDonald was sentenced to serve six years in prison with a non-parole period of three years: see Margaret Scheikowski, 'Man jailed for brother's one-stab death' (7 News, 11 July 2019). 
Both $R v$ Cliff (No 5) 323 and $R v$ MacDonald ${ }^{324}$ suggest that 'a mere scintilla' of evidence of the victim's alleged serious violent offending will be sufficient for provocation to be put before the jury. It appears also that 'serious violent offence' will encompass a wide range of behaviours including assaults, intimidation and stalking. 325 Both these factors are likely to facilitate the application of the provocation defence in cases where abused women kill their abuser. However, while assaults and non-physical abuse such as intimidation and stalking are common aspects of the pattern of domestic abuse experienced by many abused women, there is often limited evidence of their occurrence apart from the abusee's testimony. ${ }^{326}$ It is not yet clear whether the abusee's testimony about a provocative 'serious violent offence' will be sufficient on its own to meet the threshold 'mere scintilla' of evidence and ensure provocation is left to the jury. On the one hand, given the difficulties abusees face with proving domestic abuse, their testimony should be considered sufficient for provocation to be left to the jury to consider. On the other hand, such an expansive approach risks provocation continuing to be left to juries to consider in cases where abusive partners testify to their partner's provocative serious violence. As Jenny Morgan has said, 'dead women tell no tales, tales are told about them'.327 To date 'serious violent offence' has been interpreted widely, limiting the role of judges as gatekeepers of the defence, 328 leaving the question largely to the jury.

In NSW there have been no reported cases explicitly involving an accused claiming to have been provoked by the victim's choice about the relationship, so it is not clear how that will be interpreted by the courts. However, the case of $R v A 1$ (No 6) ${ }^{329}$ is of interest in this context. A1 had arranged for the victim to come to Australia to marry his daughter. The victim began an affair with A1's wife. There was evidence A1 had used tracking devices to track his wife's vehicle and conversations and discovered the affair. On the evening of the killing, AI went to the victim's house, hid behind bushes in a disguise and, when the victim returned home, A1 shot him seven times, killing him. A1 was charged with murder, but pleaded not guilty. His defence appeared to be based on 'his outrage at the conduct of the victim and the Offender's wife,

323 [2018] NSWSC 166.

$324 R v$ McDonald [2019] NSWSC 839.

325 Ibid; $R v$ Cliff (No 5) [2018] NSWSC 166.

326 Heather Douglas, 'Do we need a specific domestic violence offence?' (2015) 39 Melbourne University Law Review 434, 436.

327 Morgan (n 270 above).

328 Crofts and Loughnan, 'The good, the bad and the ugly' (n 297 above) 37.

329 [2019] NSWSC 1581. 
accompanied by feelings of dishonour' ${ }^{330}$ Historically, the provocation defence was available for men who used violence in defence of their honour and being 'cuckolded' was historically a classic provocation circumstance. 331

Provocation was not left to the jury, and the jury found A1 guilty of murder. At sentencing, AI's lawyer submitted that the conduct of the victim was provocative, pursuant to section 21A(3)(c) Crimes (Sentencing Procedure) Act 1999 and should mitigate the sentence. 332 The sentencing judge, Johnson $J$, took into account that the events leading up to the murder had a confronting effect 'arising from the victim's conduct and the honour-related cultural sentiments experienced by the Offender'. ${ }^{333}$ However, the sentencing judge found that, in this case, the 'offender's motive ... was to punish the victim for his conduct with the Offender's wife which agitated the Offender in an extreme fashion, magnified by a strong sense of dishonour'. ${ }^{334} \mathrm{He}$ further commented:

To the extent that the term 'honour killing' has been used in this and other cases, I record my immediate rejection of the concept of 'honour' as playing any part in an understanding of this crime ... the killing of a person in circumstances such as this should not attract the use of the term 'honour killing' as 'there is no honour about such an event'. 335

The judge's comments in the case show a clear refusal to blur the concept of dishonour with any lawfully recognised notion of provocation when considering sentencing. ${ }^{336}$ Rather than provocation, AI's response is identified as rooted in his 'obsessive and controlling' attitude towards his wife. 337

330 Ibid [58].

331 Graeme Coss, 'The defence of provocation: an acrimonious divorce from reality' 18(1) Current Issues in Criminal Justice 51, 63; Horder (n 277 above) 26-27.

$332 R v A 1$ [2019] NSWSC 1581 [70]; s 21A(3)(c) Crimes (Sentencing Procedure) Act 1999 (NSW).

$333 R v A 1$ [2019] NSWSC 1581 [71] and note the judge did accept that in certain cases 'circumstances of this type' are capable of constituting a form of provocation: $R v$ Khan (1996) 86 A Crim R 552, 556-557.

$334 R v A 1$ [2019] NSWSC 1581 [65].

335 Ibid [79] referring to $R v$ Khan [2016] 1 Cr App R (S) 47; [2015] EWCA Crim 1816 [23] (italics in the original).

336 Provocation is specifically identified as a mitigating factor for the purposes of sentencing in NSW, Crimes (Sentencing Procedure) Act 1999 (NSW), s 21A(3)(c).

$337 R v A 1$ [2019] NSWSC 1581 [97]. Note that A1 was sentenced to 32 years in prison with a non-parole period of 23 years' imprisonment. In contrast, note Morgan's suggestion that 'leaving "provocative" facts to the discretion of a judge in sentencing ... will do nothing to remove the gendered assumptions embodied in the current use of the provocation defence by men in situations of "sexual jealousy"': Morgan (n 270 above) 275. 
It is possible that, if Sally Challen's case had come before the NSW courts, provocation would have been left to the jury. While Challen's ex-partner's infidelity would not have amounted to a serious indictable offence, her testimony, backed up by expert evidence, that she had experienced serious violent offences such as rape at the hands of her abusive partner, may have been sufficient to leave it open to the jury. The jury would then have to be satisfied, beyond reasonable doubt, that Challen was not acting under the provocation of a serious violent offence that continued to underpin her loss of control when she killed. The presence of the hammer, Challen's recent discovery of the victim's further infidelities and the lapse of time between the alleged serious violent offence and the killing would, however, be matters the prosecution would highlight as suggesting premediated murder. ${ }^{338}$

\section{CONCLUDING COMMENTS: ALTERNATIVE APPROACHES}

In England and Wales, Qld and NSW, reforms to the provocation defence aimed to balance the aspirations of limiting the defence of provocation in circumstances where men act with proprietary entitlement over women's lives with the need to retain the defence for use by abused women who have killed their partner after experiencing abuse. Our analysis questions whether the reforms have achieved this balance. Indeed, the cases decided in relation to reforms show how difficult it is to achieve this balance through legislative reforms to the provocation defence.

In NSW and Qld the continued uncertainty and limitations around the application of the provocation defence in cases where abused women kill their abuser may be less of a concern than in England. This is because alternatives may be available. For example, in NSW an accused charged with murder might rely on the defence of 'self-defence with excessive force'. A person would be guilty of manslaughter where she used a level of force that caused death, believing it was necessary to defend herself, but the force used was not a reasonable response in the circumstances, as she perceived them. 339

338 Note as mentioned earlier, in Australia provocation is not necessarily excluded where there is 'any' interval between the provocative conduct and the accused's emotional response to it: Pollock $v$ The Queen [2010] HCA 35 (20 October 2010) [54].

339 Crimes Act 1900 (NSW), s 421 (introduced in NSW in 2001). Recall there is a maximum life penalty, rather than a mandatory life penalty, for murder in NSW: s 19A of the Crimes Act 1900 (NSW). Note excessive self-defence is also available in WA: Criminal Code Act Compilation Act 1913 (WA), s 248(3)). 
In Qld, a partial defence entitled 'Killing for Preservation in an Abusive Relationship'340 (the preservation defence) was introduced in 2010. Pursuant to this defence, the person will only be guilty of manslaughter where:

a) the deceased has committed acts of serious domestic violence against the person in the course of an abusive domestic relationship; and

b) the person believes that it is necessary for the person's preservation from death or grievous bodily harm to do the act or make the omission that causes the death; and

c) the person has reasonable grounds for the belief having regard to the abusive domestic relationship and all the circumstances of the case. ${ }^{341}$

So far, there are no reported cases where the jury has determined that the defence was applicable and found manslaughter. In at least two cases involving abused women who killed their partners, the jury was directed to consider both the preservation defence and self-defence and acquitted the accused on the basis of self-defence. ${ }^{342}$ It is difficult to imagine circumstances where a jury could be directed to consider the preservation defence without also being directed to consider selfdefence. Once the jury accepts the accused acted to preserve herself, it is a very small step for them to find self-defence. ${ }^{343}$

These NSW and Qld defences are also important as they provide an alternative option for prosecutors to charge manslaughter at the outset when abused women kill their abuser in circumstances that fall short of self-defence. Of course, some abused women who kill their abuser may be able to rely on the complete defence of self-defence, although to date this has been rare. ${ }^{344}$ In Australia, debates continue about the (appropriate) elements of self-defence and how they should be interpreted to ensure that self-defence is available, where appropriate to abused women who kill. 345

340 QCC, s 304B.

341 Ibid.

$342 R v$ Falls, Coupe, Cummin-Creed \& Hoare (Unreported, QSC, 26/5/10) per Applegarth $\mathrm{J}$ and $R v$ Irsliger, Pilkington \& Bundesan (Unreported, QSC, 24/2/12) per Mullins J. In a third case, the jury were directed to consider the preservation defence and could not make a finding, and she later pleaded guilty to manslaughter on the basis of diminished responsibility: $R v$ Ney (2011) (Unreported, QSC, 8/3/11) per Dick AJ.

343 Heather Douglas, 'A consideration of the merits of specialised homicide offences and defences for battered women' (2012) 45 Australian and New Zealand Journal of Criminology 367, 377.

344 Sheehy et al (n 29 above) 668.

345 Stella Tarrant, Julia Tolmie and George Giudice, Transforming Legal Understandings of Intimate Partner Violence (ANROWS Research Report No 03/2019, June 2019). 
In this article, we have focused our attention on provocation and, in the context of English law, reviewed the strictures presented by the CJA to successfully raise a loss of control defence when an abused woman kills her abuser. Further reform of the partial defence of loss of control is not on the political agenda and, as such, it is important to consider alternative, and adventitious, pathways to reform. New options are presented by the excessive force in self-defence adaptation in NSW, or alternatively the preservation defence in extant Qld law. This evaluation aligns with beneficial evidential alterations that should be promulgated in England that coalesce around Social Framework Evidence and enhanced jury directions that apply in Victoria and WA. Adaptation of self-defence as part of reform optimality is for future consideration. 